SARAH KASSIM DE CAMARGO PENTEADO

\title{
ESTADOS FALIDOS OU ESTUDOS FALIDOS? \\ Uma investigação acerca dos limites do Estado
}

Trabalho de Conclusão do Curso de Especialização em Relações

Internacionais para a Universidade de Brasília, apresentado como requisito parcial à obtenção do título de Especialista em Relações Internacionais 
SARAH KASSIM DE CAMARGO PENTEADO

\section{ESTADOS FALIDOS OU ESTUDOS FALIDOS? Uma Investigação acerca dos limites do Estado.}

Trabalho de Conclusão do Curso de Especialização em Relações Internacionais para a Universidade de Brasília, apresentado como requisito parcial à obtenção do título de Especialista em Relações Internacionais

Orientadora:

Prof ${ }^{a}$. Dr ${ }^{\mathrm{a}}$ Ana Flávia Granja e Barros-Platiau. 


\section{FICHA CATALOGRÁFICA}

Penteado, Sarah Kassim de Camargo

Estados Falidos ou Estudos Falidos? / Sarah Kassim de Camargo

Penteado; Orientadora: Ana Flávia Granja e Barros-Platiau. - Brasília, 2010

51 páginas.

Trabalho de Conclusão de Curso. Instituto de Relações Internacionais / Universidade de Brasília. Curso de Especialização em Relações Internacionais.

1. Estado. 2. Estados Falidos. 3. Quasi-Estados. 4. Países Menos Avançados.

Instituto de Relações Internacionais. 


\section{RESUMO}

O objetivo deste estudo é averiguar as condições para a existência do Estado e compará-las às definições de Estado falido, quasi-Estado e Países Menos Avançados. Desta maneira, procura-se ver se o Estado falido pode ser considerado um Estado de fato ou se deve ser considerado como um outro tipo de organização política. Para este estudo, é utilizada a fenomenologia como método de investigação acerca das naturezas do Estado e do Estado falido. 


\begin{abstract}
This study's intent is to look into the conditions of Statehood and compare them to the existing definitions of failed states, quasi-states and Least Developed Countries. In this manner, we try to check if the failed state can in fact be considered a state or if it should be considered some other type of political organization. We use phenomenology as our methodology for our investigation about the natures of the state and the failed state.
\end{abstract}




\section{SUMÁRIO}

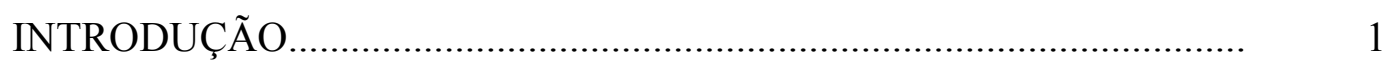

1 FENOMENOLOGIA DO ESTADO.........................................................

1.1 COMO E PORQUE NASCEU O ESTADO................................. 4

1.2 COMO É SER ESTADO?.........................................................

1.3 O QUE SIGNIFICA SER ESTADO?.......................................... 16

2 FENOMENOLOGIA DOS ESTADOS FALIDOS ...................................... 18

2.1 BREVE PANORAMA HISTÓRICO......................................... 18

2.2 O QUE É UM ESTADO FALIDO, UM QUASI-ESTADO E UM

PAÍS MENOS DESENVOLVIDO................................................... 23

2.3 COMO MEDIR A FALÊNCIA OU O GRAU DE CONSTRUÇÃO DE UM ESTADO?...........................................................

3. CONSIDERAÇÕES COM A AJUDA DA ERITRÉIA................................ 39

3.1 CONTEXTO POLÍTICO E ECONÔMICO ERITREU................. 39

3.2 ERITRÉIA: QUASI-ESTADO OU ESTADO FALIDO?............. 43

3.3 ERITRÉIA E O ESTADO FALIDO...............................................

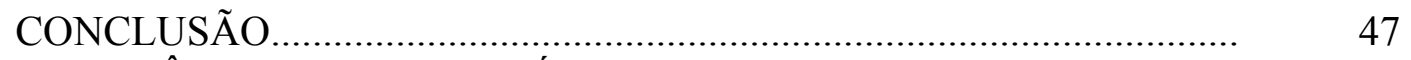

REFEERÊNCIAS BIBLIOGRÁFICAS..................................................... 


\section{INTRODUÇÃO}

\section{“ESTADOS FALIDOS OU ESTUDOS FALIDOS?”}

O tema dos Estado Falidos e dos quasi-Estados vem crescentemente ganhando a atenção de acadêmicos e espaço na mídia. Não é à toa: a enorme dificuldade de se apaziguar os conflitos internos em países tais como Somália, Sudão, Yemen e Colômbia, só para citar alguns, além de criar polaridades internas e violações aos direitos mais básicos de suas populações, podem, de acordo com alguns teóricos das relações internacionais, transbordar para outros países (spillover) e causar graves perturbações ao equilíbrio internacional. O medo de que a instabilidade e a fragilidade de alguns países contamine seus vizinhos e o cenário internacional é uma preocupação cada vez mais importante dos tomadores de decisão.

Esta visão foi especialmente adotada após os ataques terroristas de 11 de setembro. Antes dos ataques, o Estado falido era visto fatalmente como um caso de incompetência e de corrupção de seus governantes e, devido ao apelo moral das violações sistemáticas dos direitos humanos, um caso essencialmente de ajuda humanitária. Após os ataques, a agência de segurança nacional americana passou a prestar maior atenção aos Estados falidos, pois acreditava (e ainda acredita, por ser ainda um foco importante da política externa norte-americana) que estes são abrigos para os mais variados grupos terroristas . A situação caótica interna, ligada à ausência de uma autoridade repressora estimularia a instalação nestes territórios de grupos terroristas internacionais que perpetram ataques às democracias desenvolvidas (DORFF 2005) ${ }^{1}$. A questão dos Estados falidos, portanto, passou de preocupação humanitária para uma questão de segurança nacional, não apenas para os Estados Unidos, mas também para grande parte do mundo desenvolvido.

Apesar de o tema ser mais visivelmente debatido hoje em dia, os estudiosos ainda não chegaram a um consenso sobre este fenômeno. Sequer existe uma 1 DORFF, Robert H. Dorff. (2005) Failed States after 9/11: What Did We Know and What Have We Learned?. International Studies Perspectives. Vol. 6, páginas 20-34 
definição precisa do que seja o Estado, fato que cria imensas dificuldades na hora de se definir quando ou o que o fez falhar. A formação de Estados durante o século XX, em meio à formação do mundo contemporâneo deu-se de maneira debilitadora, em meio a brigas, entre outras, acerca das identidades locais, regionais e internacionais. Os países hoje conhecidos como Estados falidos não tiveram, antes de se tornarem de fato estados falidos, uma formação apropriada. Não foram, anteriormente, Estados de fato. Portanto, a denominação de "estado falido" torna-se questionável por não condizer com a realidade: se não eram Estados, como então tornaram-se Estados falidos?

Torna-se necessário, portanto analisar mais de perto no que implica o termo Estado falido e se ele realmente explica ou não a situação da maioria dos países do mundo. Para isto torna-se imprescindível voltarmos à definição de Estado e tornar claro as condições para sua existência. É preciso também investigar as implicações do Estado falido em comparação com outras denominações existentes, tais como os quasi-Estados e Países Menos Avançados (PMAs).

Proponho questionar alguns dos argumentos existentes sobre os Estados falidos sob a perspectiva fenomenológica na tentativa de achar pontos de vista alternativos acerca do Estado. A fenomenologia a partir dos estudos de Edmund Husserl, filósofo alemão do início do século XX. A proposta do estudo fenomenológico é confrontar os fenômenos existentes de maneira a não reduzi-los a meras descrições, mas buscar a sua essência ou, em termos platônicos a sua idéia. A busca pela ontologia vai além da superfície, buscando desvelar como os diferentes aspectos que compõe o objeto são constituídos de forma a criar a experiência para o observador .Em outras palavras, o mundo é composto por sujeitos e objetos, e a compreensão dos objetos que estão no mundo depende da maneira como olhamos. A fenomenologia propõe uma espécie de revolução copernicana do sujeito em volta do objeto. Assim é possível perceber os diferentes elementos que compõe o objeto na busca pelo entendimento de como da ontologia do objeto, ou seja, como é o seu modo de ser, o que o caracteriza e quais são seus limites. Um estudo fenomenológico acerca do Estado ainda não existe, portanto este trabalha compõe um ensaio acerca dessa possibilidade. 
A pergunta principal do trabalho é acerta da busca ontológica do Estado falido: o que significa ser um Estado falido? Quais os atores desse Estado e a dinâmica de interação desses atores? Existe uma razão comum que perpassa a falência de vários Estados atuais? Qual o alcance de suas perturbações internas? É possível, de fato, que os Estados falidos abalem a ordem internacional?

No primeiro capítulo voltamos à sociologia do Estado e à história das relações internacionais para resgatar as características do Estado, o que torna o Estado um fenômeno político diferente das experiências anteriores e quais os seus limites. Buscamos compreender a ontologia do Estado, o que a existência do Estado implica para a sociedade e para o sistema político.

No segundo capítulo procuramos buscar algumas definições de Estados falidos, seus limites e compará-las entre si e entre a definição de quasi-Estados de Robert Jackson e de Países Menos Avançados, das Nações Unidas. Buscamos delimitar os aspectos levados em consideração por cada termo na definição de um país como tal. Procuramos também apresentar os diferentes índices de classificação, tais como o Failed State Index e os critérios para a classificação como PMA

No terceiro capítulo pegamos o exemplo da Eritréia, que se encaixa nos dois índices apresentados no capítulo anterior e procuramos mostrar como eles analisam aspectos diferentes mas que, se considerados conjuntamente, podem dar indícios acerca de como anda o Estado no país escolhido. Entretanto, são insuficientes para dar um veredicto acerca do funcionamento de suas instituições políticas, o que realmente importa para a definição de Estado, se são fortes, fracas ou inexistentes.

As conclusões tiradas deste estudo apontam para como as deficiências na definição do Estado tornam impeditivas a definição de Estado falido. A análise dos critérios para falência ou para classificação como PMA/quasi-Estado/Estado falido permitiram extrair uma nova função do Estado nascida durante o século XX: a de protetor e garantidor dos direitos humanos e como esta nova função dificulta mais ainda o processo de construção do Estado sob ameaça do escrutínio internacional. 


\section{1 - FENOMENOLOGIA DO ESTADO}

A diversidade existente das formas nas quais se apresenta o Estado nos leva a questionar acerca de sua definição. O que é um Estado? O que o caracteriza? Os exemplos materiais de Estado que temos no mundo são, de fato, Estados? Ou são estes outros tipos de instituições políticas? Estas questões tornam-se necessárias a partir do momento em que o Estado moderno é visto como a maneira universal de se institucionalizar o arranjo político de todas as sociedades, independente de suas trajetórias históricas. Esta generalização possui um passado de imposições forçadas de regimes, desmerecendo arranjos sociais, políticos e culturais locais, tornando a adoção da forma Estatal talvez inadequada em diversos casos. A compreensão do que é um Estado, suas características e funções podem ajudar a compreender o seu lugar no mundo atual.

\section{1 - Como e Por que nasceu o Estado?}

Para os teóricos das Relações Internacionais, o Estado moderno surge com a Paz de Vestfália que encerra a guerra dos 30 anos em 1648 ao forçar a Igreja católica a reconhecer o Estado como poder supremo dentro de fronteiras estabelecidas (HERZ 1997)2. A independência adquirida em relação à Igreja vem acompanhada da soberania, ou seja, o poder de decidir quais rumos políticos, econômicos e militares a sociedade dentro do território estabelecido tomará, autonomamente de qualquer influência externa. Soberania e autonomia são as características mais importantes do Estado que surge, pois são os elementos que diferenciam o sistema político alcançado do anterior. Os primeiros Estados nascem como territórios políticos independentes que possuem suas próprias leis, não estando sujeitos a qualquer poder exterior. $\mathrm{O}$ Estado nasce para tornar viável um governo central autônomo que responda às

2 HERZ, Mônica. Teoria das Relações Internacionais no Pós-Guerra Fria. Dados, Rio de Janeiro, v. 40, n. 2, 1997. Disponítvel em: http://www.scielo.br/scielo.php?script=sci arttext\&pid=S001152581997000200006\&lng=en\&nrm=iso. Acesso em: 12 Fev. 2010. doi: 10.1590/S001152581997000200006. 
necessidades de um determinado território. Os países que melhor exemplificam esta fase são os Estados Unidos e a França porque foram os primeiros a executarem estas mudanças, aplicando por completo todos elementos que caracterizam o Estado como tal. O modelo político do Estado é, a partir deste ponto, completado e diferenciado dos sistemas políticos anteriores.

A segunda leva de nascimentos de Estados se dá no início do século XIX, na Europa, enviesada pelo nacionalismo (HOBSBAWM 1996a) ${ }^{3}$. Pessoas que se identificavam por meio de uma cultura e de um idioma buscavam independência do domínio por outros povos. A formação do Estado então passou não apenas a considerar a separação entre religião e política, mas também entre nacionalidades. Estes novos Estados nascem após a Revolução Francesa incitar a mudança nas formas de poder tradicionais européias. A emergência dos novos Estados vem acompanhada dos ideais iluministas, ou seja, uma maior distribuição do poder na sociedade - embora esta não seja plena. São exemplos desta segunda leva a Itália, a Bélgica, a Alemanha.

A terceira leva de formação de Estados ocorreu entre o final do século XIX e início do século XX, com as independências ocorridas na América Latina. O que diferencia esta formação das anteriores é a situação de ex-colônias dos novos Estados. Durante a colonização, a região teve seus regimes econômicos e políticos impostos, ambos voltados para satisfazerem as necessidades das metrópoles. Após a independência, os países latino-americanos adotaram as formas de Estado já existentes, assimilando-as de maneira a se adequarem às especificidades culturais locais. Em grande parte dos casos, não houve uma redistribuição de poder. A elite dos países permaneceu, na maior parte, a mesma - assim como o modo de produção. As estruturas políticas voltaram-se para legitimar e perpetuar as oligarquias existentes. A baixíssima industrialização da região até o século XX não formou uma massa proletária contestatória, não aprofundou a divisão do trabalho na região. As relações clientelísticas permaneceram. A formação dos Estados na América latina, portanto, teve causas diferentes das que proporcionaram a formação dos Estados Europeus. Não aconteceu por causa de uma ruptura com a Igreja. Não houve uma história de

3 HOBSBAWM, Eric. 1996a. Age of Revolutions: 1789-1848. Nova Iorque, Vintage Books. 368 páginas. 
passado feudal. Não houve uma crise institucional. As nacionalidades nesta região sequer estavam estabelecidas. $O$ que ocorreu foram casos de mimetismo institucional. A região não criou uma nova forma institucional de gerir o país. Ela adotou o que os modelos institucionais que funcionaram em outras regiões, cujos exemplos mais significativos eram os Estados Unidos e a França.

A quarta leva de formação de Estados se deu com a descolonização da África e da Ásia, ocorridos após o final da $2^{\text {a }}$ Guerra Mundial com a incapacidade das metrópoles, arrasadas pelas guerras, de manterem o regime colonial. Apesar de generalizações, estas levas coincidem com acontecimentos históricos de significativa mudança na forma de organização da política nacional nestas diferentes regiões.

Com a queda da União Soviética e a formação de novos países independentes houve uma quinta leva da formação de Estados. Entretanto, antes de se unirem à União Soviética, forçosamente ou não, a formação Estatal já havia ocorrido nos membros cooptados. A formação estatal prévia fora, no entanto, englobada e dissolvida na União Soviética. A anexação territorial e o governo baseado em Moscou, acompanhados de significativa perda da soberania e da autonomia, levaram à formação de um grande Estado soviético, ao invés da União de diversos Estados. A dissolução da URSS engendrou um novo processo de diferenciação, construção e modernização Estatal no centro e leste europeu.

Apesar de servir como inspiração para muitos dos movimentos de independência na América Latina, a formação do Estado nos Estados Unidos, de certa forma, também é um caso de mimetismo institucional. Yves Méni (1993) criou este conceito $^{4}$, que se resume na reprodução das instituições políticas européias em outros cantos do mundo. Esta reprodução vem acompanhada de adaptações culturais locais que acabam por diferenciar as recém-criadas instituições de suas matrizes. O modelo político europeu foi adaptado e reproduzido em todo o resto do mundo, tornando-se o modelo universal e "normal". Busca-se o enquadramento das outras nações no sistema de Estados, procurando estabelecer valores e normas comuns. Como em todo o resto das Américas, não houve um passado feudal na região. 
Degredados ingleses estabeleceram-se no noroeste do atual território estadunidense, porém dispunham de certas "regalias" com que as outras colônias não contavam: as treze colônias tinham relativa liberdade de fabricação (NETTELS 1952) 5 . Desenvolveram uma indústria local que permitiu certa autonomia econômica em relação à metrópole inglesa. Resumidamente, a crescente liberdade econômica levou a uma crescente autonomia política. Esta autonomia, tornada plena com a declaração de independência de 1776 e a edição do Bill of Rights americano, entretanto, não fugiu dos padrões nos as quais a política no Reino Unido era realizada. O Estado foi formado e, apesar de não seguir o mesmo regime político, as estruturas de suas instituições políticas em muito se assemelhavam.

As instituições políticas no Reino Unido eram diferentes do resto da Europa desde que a Revolução Gloriosa cortou os poderes da coroa em 1688, fortalecendo o parlamento. A situação geográfica do arquipélago garantia uma autonomia em relação ao continente, além da delimitação de um território específico. O governo centralizado e aceito por boa parte da população deste território permitiu o exercício da soberania e a relativa separação com relação ao continente (baseado numa marinha forte) facilitou a auto-determinação. O governo central detinha o monopólio da lei e da força, governando diretamente seus cidadãos, apesar deste termo ter, naquela época, escopo limitado - não havia eleições diretas para os membros do alto parlamento, por exemplo. Estas características estruturais do Estado, de acordo com Hobsbawm $(1996 b)^{6}$ foram utilizadas como base para a formação do Estado norteamericano, embora os ideais iluministas estejam presentes também. Ao invés de monarquia, presidencialismo regulado por um congresso forte. $\mathrm{O}$ regime relativamente democrático adotado não vem como surpresa, visto que o motivo que levou à luta pela independência foi o impedimento da representação das colônias no parlamento britânico e, consequentemente, a impossibilidade de interferir no próprio destino político e econômico..

A importância da independência dos Estados Unidos foi a associação entre o

5 NETTELS, Curtis. British Mercantilism and the Economic Development of the Thirteen Colonies. Journal of Economic History. Vol. 12, Spring n², 1952. Páginas 105-114.

6 HOBSBAWM, Eric. 1996b. The Future of the State. Developmente and Change, vol. 27, n. 2, páginas 267-278. 
Estado e a democracia. O Estado devia moralmente operar como democracia ${ }^{7}$, pelo menos entre os colonos homens brancos, visto que a escravidão e a segregação racial ainda foram mantidos por um bom tempo. Esta idéia de algum nível de participação popular no destino dos Estados fora incendiária para a realidade européia e contribuiu para as revoluções que viriam. A mais importante e radical foi a Revolução Francesa, que marcou o fim do feudalismo na Europa ocidental. As transformações econômicas que ocorreram com o mercantilismo e a industrialização criaram novas divisões de trabalho dentro da sociedade. Não existiam apenas os nobres e os servos, mas também a burguesia e o proletariado que ficaram excluídos da divisão de poderes, juntamente com os camponeses. A paz de Vestfália de 1648 já havia alterado as formas de poder, dissociando o mando da igreja do mando do Estado, a religião da política. Entretanto, faltava ainda incluir a população no mando do Estado.

A importância da Revolução Francesa está na dissolução das solidariedades tradicionais e das especializações dos papéis sociais, com o conseqüente rearranjo da sociedade civil, advindo da liberação de recursos de poder das antigas hierarquias e a difusão desses recursos de poder, juntamente à criação de novos poderes, entre grupos autônomos que escapam de um controle totalmente exclusivo. De acordo com Badie e Birnbaum (1982, p.56-57) ${ }^{8}$, baseados em Talcott-Parsons, estas são as características essenciais que marcam a diferenciação do Estado em relação aos outros sistemas políticos anteriores. Isto porque a diferenciação dos grupos sociais e a generalização do poder requerem a formação de um processo de expressão de demandas, de politização dos interesses e conflitos, resultando na universalização do campo político. Este mesmo processo acelera as condições da diferenciação social, re-alimentando o processo de autonomização do poder. Desta maneira, o Estado moderno nasce como um mecanismo auto-regulador do novo mercado de recursos políticos. Suas funções são de organizar a luta política e a participação nela. Para que esta função seja possível, a centralização das estruturas políticas faz-se necessária

7 A posterior afirmação do Destino manifesto, na década de 1830, elabora o dever moral de se expandir a democracia por todo o continente americano, mas desde a formação dos Estados Unidos, a moralidade está sempre acompanhada do dever ser do Estado.

8 BADIE, Bertrand et BIRNBAUM, Pierre. Sociologie de l'État. Paris, Grasset, 1982. 238 páginas 
para facilitar a coordenação política e assim atender às necessidades e desejos da população. De maneira mais simples: a abertura da política a outros grupos e classes sociais (embora não plena) e o conseqüente aumento da acessibilidade aos instrumentos para a formação de demandas regulada por uma burocracia especializada, acompanhados da autodeterminação e da soberania são características exclusiva do sistema estatal nascente.

Badie e Birnbaum (1992 p.57) enfatizam o caráter de ruptura sistêmica que a criação do Estado implica. O Estado surge para criar condições de governabilidade em uma situação em que o poder fora mais ou menos distribuído num determinado território e que, portanto, possui mais gente querendo legitimamente influir nos rumos da sociedade. A criação do Estado é uma resposta possível (e nova) resultante desse processo. É uma resposta da população a um contexto de subjugação na busca por uma maior abertura e participação política, laicização das esferas pública e privada, com a conseqüente criação de novas identidades sociais. É importante frisar que embora ocorra certa distribuição de poder e o rompimento de algumas alianças tradicionais, este processo não é universal. Setores da população ainda permanecem excluídos e subjugados, como as mulheres e os escravos. Em muito casos também a população mais pobre, como ocorreu por muito tempo no Brasil. Serão necessárias as duas grandes guerras para de fato universalizar a participação política no mundo desenvolvido.

A Revolução Francesa é um marco histórico importante porque conclui de maneira radical o processo de diferenciação do Estado como sistema político, servindo de inspiração para transformações no resto da Europa ocidental e central. A independência dos Estados Unidos foi a pioneira do processo da ruptura histórica do sistema político, mas a revolução francesa marca a aceleração e a radicalização deste processo.

Para Badie e Birnbaum (1982), para que o Estado nasça há um conjunto de características internas e externas intrínsecas ao sistema político nacional que são interdependentes. Sem a combinação destes fatores o surgimento do Estado não teria ocorrido. Dentre as características internas estão o passado feudal, as transformações 
sócio-econômicas advindas da industrialização e da nova divisão do trabalho. $\mathrm{O}$ passado feudal é importante pois são de suas instituições políticas que o Estado irá se diferenciar. As transformações sócio-econômicas ocorridas na era moderna devido ao mercantilismo e à industrialização criaram novos setores dentro da sociedade que não tinham representação ou poder político. As revoluções ocorridas no século XVIII e XIX tiveram o intuito de realocar o poder dentro da sociedade de forma a distribuí-lo. Dentre as características externas estão o sistema econômico internacional, a difusão do Direito Público Romano, as pressões militares e as migrações (BADIE e BIRNBAUM, p.87-88). O desenvolvimento do capitalismo tornou o modo de produção feudal obsoleto. A criação e o crescimento de grandes mercados mundo afora, tanto fornecedores quanto consumidores, mudou e intensificou o modo de produção na Europa, acirrando a divisão social. O desenvolvimento do capitalismo incentivou o desenvolvimento da industrialização. A difusão do direito público romano no cenário internacional serviu para homogeneizar as relações entre as nações, seus direitos e deveres, o que não ocorreu sem adaptações dentro de cada sociedade. As pressões militares acirravam-se, sobretudo, no poder que cada Estado tinha de manter seus mercados consumidores. Desta forma o desenvolvimento econômico era assegurado, o que intensificava a divisão social do trabalho. As migrações, tanto internas quanto externas aumentavam as pressões sobre a divisão do trabalho.

Como estas características criaram o Estado? O Estado foi uma resposta para a crise política européia, não um fim em si mesmo. Ele responde à quebra na divisão tradicional do poder e adequa as novas estruturas e demandas do poder. Sua implementação não ocorreu sem resistência de setores e instituições tradicionais e esta é a razão pela qual existem diferentes arranjos entre burocracia e poder político, executivo e legislativo, Estado e estruturas religiosas, economia e política nos Estados existentes (BADIE E BIRNBAUM 1982, p.88-89). Tais arranjos servem para acomodar as singularidades de cada sociedade. O Estado não é uma instituição homogênea.

O que a realidade histórica nos mostra, entretanto, é que o surgimento de muitos Estados, em especial fora da Europa, não ocorreu com as mesmas condições 
que tornaram os Estados nacionais europeus o que são. Como são regiões diferentes, as condições históricas e estruturais que se apresentam não são as mesmas. Nas Américas, por exemplo, não houve um passado feudal. Como regiões periféricas às metrópoles européias, o sistema político implantado era bastante restritivo. Cumpriase na colônia o que era determinado pela metrópole, excluindo os colonos do processo decisório. Da colônia era esperado o fornecimento de matérias-primas para o desenvolvimento econômico e industrial das metrópoles, além de um mercado consumidor para o que era produzido. Os sistemas político e econômico instaurados nas colônias eram impostos de modo a complementarem as atividades das metrópoles e só. Embora não houvesse um passado feudal per se, todavia houve um passado de submissão, de estrangulamento da autonomia em nome da metrópole. E esta submissão ocorreu enquanto foi favorável às elites coloniais. A partir do momento em que as elites exigiram sua autonomia política e, sobretudo, econômica, iniciou-se o processo de independência nas Américas. Entretanto, a formação do Estado nesta região não foi acompanhada, na maioria dos casos, de uma variação dos grupos sociais e da generalização do poder. De forma geral, o processo de independência ocorreu sem uma grande participação popular, ficando o poder concentrado nas oligarquias que a incitaram. O modelo político a ser implementado, entretanto, foi adotado a partir de exemplos que demonstraram ser as novas formas dominantes de política.

De criação a partir de um conceito histórico particular para a sua mimetização em diversas partes do mundo, o Estado perde neste pulo a sua especificidade histórica e geográfica. Todavia, a adoção do Estado no resto do mundo e a adaptação de suas instituições de governo apenas enfatizam o fato de que o Estado não é um fenômeno único e restrito a determinadas condições. O alargamento do conceito de Estado ocorreu com a sua mimetização, e a historicidade deixou de ser importante para a sua definição. Os elementos significativos para a definição do Estado passaram a ser as instituições que o compõe e se elas estão de acordo com os ditos valores universais e, consequentemente, com o contexto político-econômico dominante ocidentais. 
Para Badie e Birnbaum (1982), a criação do Estado implica uma maior participação popular na tomada de decisões. O interesse coletivo está em questão. A esfera pública é criada de maneira a tentar reproduzir a esfera privada no que se refere ao atendimento das vontades individuais e coletivas. Os interesses se encontram e divergem, cabendo ao Estado filtrar os interesses mais comuns que outros. A maior participação política e o aumento dos canais de demanda implicam um maior contingente de atores políticos. Essa abertura, entretanto, não significa participação das massas. O Estado abre possibilidade para participação aos mais interessados, a quem procura efetivamente participar da esfera política, embora nem todos compitam sob as mesmas condições. O Estado proporciona um palanque, uma abertura política para sua população, mas não garante a participação.

Apesar de uma certa democratização do poder ocorrer, não é possível associar a democracia ao modo de ser do Estado. Badie e Birnbaum (1982), entretanto, incorrem nesta associação. A quebra das estruturas tradicionais de poder, a disseminação do poder nos diferentes grupos sociais e o conseqüente empoderamento de diversos grupos diferentes são, para Badie e Birnbaum o que levam à formação do Estado moderno. Pois esse empoderamento requer uma instância reguladora, que seja um fórum para que os diferentes grupos externem seus desejos político-econômicos sendo capaz de captar a vontade geral e conduzir os assuntos de Estado com base nela. A difusão do poder por meio da sociedade caracteriza o Estado moderno. Isto é feito por meio de uma reorganização dos papéis e das classes sociais, com novos grupos antes impedidos obtendo acesso ao poder, e as antigas elites perdendo seu status privilegiado. Esta característica, entretanto, não contabiliza a existência dos regimes totalitários, das ditaduras civis e militares que freqüentemente se criam nos Estados modernos.

\section{2 - Como é ser Estado?}

A definição tradicional de Estado, de acordo com Reuter, inclui três elementos fundamentais: um território delimitado, uma população e um governo 
capaz de assegurar as funções internas e externas do Estado ${ }^{9}$. Cabe ao governo instaurar uma ordem jurídica e material interna que traga estabilidade ao território e à sua população (REUTER 1980, p. 139). Esta é a definição seguida pelo direito internacional atual mas, de acordo com Brownlie (1979 apud MILLIKEN e KRAUSE, 2003, p.11) ${ }^{10}$, a caracterização do Estado era bem mais simples na década de 1930: existência de um governo efetivo, com administração central e órgãos legislativos. A não-menção ao território deixa entender que se uma cidade que possui todas as caraterísticas citadas deseja tornar-se um Estado, isto será possível. A nãomenção à população deixa entender que a legitimidade deste governo perante o povo não é relevante para a denominação ou não do Estado. Devido a esta caracterização, de acordo com Milliken e Krause (2003, p.11), durante o período de descolonização das décadas de 1950 e 1960, muitos dos Estados que nasceram foram considerados como Estados, o que gerou inúmeros problemas institucionais posteriores.

Hobsbawm (1996b, p.268) acrescenta às características mencionadas por Reuter e Brownlie a soberania, o monopólio da lei e da força, e a estandardização do tratamento para com os cidadãos. Para ele, a legitimidade do Estado advém do povo que representa, sendo o Estado a realização de uma vontade popular ${ }^{11}$. Ou seja, o Estado é um espaço delimitado que contém uma população e um governo soberano que possui o império da força e da lei e que é legitimado pela sua população. Devido a esta característica, o Estado deve um tratamento jurídico igualitário aos seus

9 REUTER, Paul. Instituições Internacionais. Prefácio de Antônio da Costa Lôbo. Lisboa, Edições Rolim: 1980373 páginas.

10 BROWNLIE (1979) citado em: MILLIKEN, J \& KRAUSE, K. State Failure, State Collapse and State Reconstructuion: Concepts, Lessons and Strategies. In: MILLIKEN, Jennifer (ed.) State Failure, State Collapse and Reconstruction. Cornwall, Blackwell Publishing, 2003. 325 páginas.

11 De acordo com Hobsbawm (1996b), estas são as características definidoras do Estado: $1^{\circ}$ território separado de outros Estados por fronteiras claramente estabelecidas, que demarca os limites do poder de um governo de outro. $2^{\circ}$ _este território é soberano; $3^{\circ}$ dentro deste território o Estado tem o monopólio da lei e dos poderes de coerção (exceto no caso da União Européia, no qual os Estados-membros renunciaram leis locais em favor da lei européia); $4^{\mathrm{o}} \ldots$ Estado nacional governa seus cidadãos diretamente, e não por meio de autoridades intermediárias (que são diferentes da diferenciação entre governo central, regional e local); $5^{\circ}$ _ governo e administração centrais dos cidadãos implica numa homogeneização da maneira de tratar os cidadãos; $6^{\circ}$ _ a herança da era das revoluções transformou os Estados em estados de cidadãos, pelo menos na teoria. O Estado representa seu povo, sendo o povo a fonte da soberania ou, no mínimo, a fonte de legitimidade do governo. O que não implica que os Estados-cidadãos sejam democráticos. 
cidadãos, as mesmas leis que valem para um valem igualmente para outro, o mesmo para as proibições. Hobsbawm atualiza a definição weberiana ao acrescentar o princípio da igualdade entre os cidadãos. De certa forma, Badie e Birnbaum também levam em conta este fator por associarem a difusão do poder ao elemento diferenciador do Estado como sistema político. O tratamento igualitário dos cidadãos, com leis que regem igualmente a todos aprimora a organização política social, proporcionando, teoricamente, uma base comum para a participação política. A distribuição do poder e a sua difusão na sociedade é uma das características mais relevantes do Estado e a mais esquecida.

Badie e Birnbaum (1982) citam a existência dos três poderes (legislativo, executivo e judiciário e o equilíbrio entre si) como fator inexorável do Estado para prover a organização política. O desequilíbrio entre estes poderes, e até o descumprimento deste princípio,, como é visto em muitos Estados atuais (Coréia do Norte, Eritréia, Venezuela), entretanto, não são suficientes para descaracterizar o Estado como Estado. Apesar de afirmarem a importância dos três poderes e a conseqüente divisão entre eles, Badie e Birnbaum não mencionam a importância da constituição escrita, elemento extremamente importante na questão da diferenciação do Estado de sistemas políticos prévios. Para Hobsbawm (1996b) a constituição é uma característica bastante importante na diferenciação entre o Estado moderno e o sistema feudal. Isto porque ela implica que a criação das regras sociais gerais e sua implementação é um processo que deve ter o aval do povo, retirando assim a arbitrariedade dos governantes na hora de criar e impor as leis. Após a Revolução Francesa, que radicaliza o processo de criação da constituição, um regramento coletivo que firma o pacto social de determinado estado, criado pelo povo e para o povo, sua larga aceitação e implantação caracteriza o Estado moderno. A constituição compõe o conjunto das regras acordadas que regulam o funcionamento da sociedade, que garante a distribuição do poder e a própria divisão do poder. A constituição é o elemento organizador do Estado, regrando o funcionamento de suas instituições e firmando que tipo de pacto existe na sociedade. A constituição é a base para a construção das instituições estatais. 
As características acima mencionadas são abrangentes o suficiente para que qualquer governo que as cumpra possa ser caracterizado como um Estado. O problema surge quando estas características são "maquiadas", ou seja, não são realizadas a fundo, apenas dando a aparência de existirem. Regimes autoritários, por exemplo, redistribuem o poder para atender apenas a quem manda. O governo se instala no poder sem no entanto representar a população como um todo. A rotatividade dos líderes é estancada. Exemplos marcantes no século XX de Estados assim descaracterizados foram as ditaduras do Cone Sul e da Península Ibérica. Estas distorções, no entanto, não foram suficientes para que o senso comum desassociarem-na do Estado.

A história recente mostra exemplos de leniência com estas distorções. A difusão do Estado como forma de realizar a política e a sua propagação mundo afora universalizou-o como a única maneira, a única resposta possível de organização política moderna. O que varia são os regimes adotados por cada Estado. Esquece-se que antes de existir o Estado existiram outras organizações políticas, e que o Estado surgiu como uma resposta para uma crise específica. Sua universalização é conseqüência do imperialismo europeu no século XIX, mimetisado por representar o que era considerado ser o mais moderno e desenvolvido dos mundos.

No século XX a hegemonia européia dá lugar à hegemonia estadunidense. Observamos aqui também uma nova subversão do Estado. O modo de ser, o regime legítimo representativo do Estado tornou-se a democracia, com a sua imposição aos países que dela "desviam" (ESTADOS UNIDOS, 2003) ${ }^{12}$. Esta democracia de que se fala, entretanto, é diferente da difusão do poder acima mencionada. A institucionalização da democracia como regime político e o estabelecimento de seu dever ser variam imensamente com a concepção política de cada sociedade, com o

12 O "NATIONAL STRATEGY FOR COMBATING TERRORISM" de 2003, lançado pela presidência dos Estados Unidos apenas confirma o que a política externa já vinha realizando desde o final da Guerra Fria. Com a afirmação da hegemonia estadunidense vê-se a vilipendiação de Estados que seguem regimes não-democráticos e hostis aos Estados Unidos, como o Iraque, a Coréia do Norte, o Irã. A democracia passa a ser o único regime moralmente correto. Ver: ESTADOS UNIDOS_ Executive Office of the President. National Strategy for Combating Terrorism. Fevereiro 2003, 30 páginas. 
seu passado cultural, com a sua história. A imposição de um modelo único de democracia, que segue os parâmetros estadunidenses fere a constituição individual de cada Estado, que possui seus arranjos próprios baseados em sua cultura política. A difusão do poder na sociedade por si só não é garantidora da existência da democracia. Associada à homogeneização do tratamento dos cidadãos, a democratização variará de acordo com as leis locais.

A imposição de uma maneira única do modo de ser do Estado também o desconfigura. Isto porque existem inúmeras maneiras de se conjugar território, população, governo soberano e legitimado pelo povo, espaço político centralizado e organizador das relações políticas, divisão de poderes. Fato é que o modo de ser do Estado sempre fora de alguma maneira imposto pelas potências ${ }^{13}$, numa tentativa de manipular as relações bilaterais de forma a favorecer o mais forte. É preciso sempre lembrar que o sistema internacional de Estados é composto por relações assimétricas. Existem Estados mais fortes que outros e que possuem uma capacidade de interferência mais forte que a capacidade de defesa de muitos outros Estados, e vantagem é bastante usada. Hoje vivemos em um mundo multipolar sem multilateralismo, o que cria um problema de liderança: quem manda no mundo? As disputas entre as potências acabam por afetar todos os outros Estados, tanto na sua formação, quanto no seu andamento, até em sua intervenção ou não. Após tantas descaracterizações, nos resta então a pergunta: o que significa ser Estado?

\section{3 - O que significa ser Estado?}

Os passados cultural e político das sociedades que adotaram o estado são os mais variados possíveis, e não possuem as mesmas condições que criaram o Estado na Europa. O conceito fora adaptado às diversas condições locais, perdendo o seu significado original. Em muitos dos lugares em que foi adotado, inicialmente a

13 Por exemplo, os casos da China na guerra do ópio, os tratados desiguais da Grã-Bretanha com as regiões periféricas, a Guerra Fria inteira, com suas esferas de influência e o embargo até hoje imposto pelos Estados Unidos a Cuba. Ver HOBSBAWM, Eric. Age of Empires: 1875-1914. Nova Iorque, Vintage Books: 1989, 404 páginas. 
implementação do Estado nacional ocorreu sem diversificar o empoderamento na sociedade, mas por muito tempo apenas fortaleceu as relações de poder tradicionais. Ou seja, o Estado serviu tanto para alterar as relações de poder nas sociedades como também perpetrar as já existentes. Este fator é extremamente importante, pois

A construção de Estados soberanos é um processo principalmente doméstico, que ocorre ao longo de extensos períodos de tempo e só pode funcionar quando há a combinação de interesses, esforços e responsabilidade de governantes e população ${ }^{14}$ [RODRIGUES 2001, p. 141].

Organizar a política de uma determinada maneira é diferente de organizá-la de outra. O Estado possui um conjunto de características que o diferenciam de outros sistemas políticos. Se estas características são descumpridas, é possível dizer que ainda existe um Estado? Na realidade observa-se certo descaso quanto à observância destas características, o que acaba por, de fato descaracterizá-lo. A crescente abrangência do termo Estado requer redefinições constantes. Sem saber seus limites, no entanto, torna-se difícil delimitar outros sistemas políticos e até corrigir falhas dentro deste.

A idéia de Estado também está associada ao reconhecimento de que existe. O reconhecimento internacional oficial por outros Estados não está em questão, mas simplesmente o fato de que a existência do Estado é percebida por outros (DI JOHN, 2008$, p.5 $)^{15}$. A redução do sistema político ocorre quando supomos que o único sistema político em existência atual é o Estado. Simplesmente o fato de um território delimitado existe com algum tipo de governo é suficiente para acreditá-lo como Estado. Ser Estado, no entanto, implica em muito mais. Se algumas de suas características estão propositadamente ausentes, o sistema político, ou o sistema está a caminho de se tornar um Estado ou, simplesmente, não é um Estado.

14 RODRIGUES, Simone M. Inserção Internacioal de Quasi-Estados no Século XX: A Política das Nações Unidas. Revista Cena Internacional 3 (1), 2001. Páginas 133-152.

15 DI JOHN, Jonathan. Conceptualizing the Causes and Consequences of Failed States: A Critical Review of the Literature. In: Crisis States Working Paper $n^{\circ} 25$ Series $^{\circ}{ }^{0}$, London, LSE Development Studies Institute: 2008, 51. 


\section{2 - FENOMENOLOGIA DOS ESTADOS FALIDOS}

\section{1 - Breve Panorama Histórico}

O período que se seguiu ao final da Segunda Guerra Mundial observou o crescimento em uma escala nunca vista antes do número de Estados nacionais. De acordo com Rotberg,

In 1914, in the wake of decline of the Ottoman and Austro-Hungarian empires, there were fifty-five recognised national polities. In 1919, there were fifty-nine nations. In 1950, that number reached sixty-nine. Ten years later, after the independence movements in Africa, there were ninety nations. After more African, Asian, and Oceanic territories became independent, and after the demise of the Soviet Union, the number of nations increased dramatically to 191; East Timor's independence in 2002 brought that total to 192 (ROTBERG 2003 apud DI JOHN 2008, p.5).

As duas Guerras Mundiais, acrescidas das centenas de guerras de independência e de construções nacionais posteriores, sob influência da Guerra Fria, viram atrocidades como nunca antes vistas. De acordo com Hobsbawm (1995, p.21) $)^{16}$, "no Breve Século xx mais homens [foram] mortos ou abandonados à morte por decisão humana que jamais antes na história”. As atrocidades ocorridas durante o período das guerras levaram à crescente valorização dos direitos humanos (BAS ART 2004) ${ }^{17}$. O aumento do número dos Estado foi acompanhado de uma crescente preocupação com os direitos humanos, da necessidade de preservá-los

16 HOBSBAWM, Eric J. A Era dos Extremos: O Breve Século XX: 1914-1991. Tradução de Marcos Santarrita; Revisão Técnica de Maria Célia Paoli. São Paulo, Companhia das Letras, 1995. 632 páginas

17 BAS ART. Non-State Actors in Global Governance: Three Faces of Power. 2004. 54 páginas. Tese de Doutorado - University of Nijmegen. Bonn, abril de 2003. Tese digital pág. 27 Disponível em: http://www.essex.ac.uk/ecpr/events/jointsessions/paperarchive/edinburgh/ws11/arts.pdf. Acesso em: 19/03/2010. 
e do acréscimo da proteção aos direitos humanos às funções do Estado. A busca por modos de se assegurar a segurança humana levou à criação da Organização das Nações Unidas e à consequente valorização do Estado nacional como único sistema político capaz é de proteger seus cidadãos.

A exaustão das metrópoles européias devido às guerras levou à sua decadência como potência, cedendo lugar ao novo hegemon, os Estados Unidos. A necessidade de voltarem suas atenções para a própria reconstrução fez com que as metrópoles estivessem menos aptas e capazes de atenderem às necessidades de suas colônias. Associadas à emergência do conflito bipolar, foi desencadeado o processo de descolonização no período do pós-guerra. A criação da ONU acompanhada da afirmação do princípio de autodeterminação dos povos serviu de justificativa moral para o desmanche do pacto colonial.

O processo de descolonização da África e da Ásia, que diz respeito ao período em questão, não se desenrolou pacificamente. Como as antigas metrópoles estavam exauridas de recursos financeiros e dependiam da ajuda financeira dos Estados Unidos para restaurarem a antiga glória, não conseguiram abafar os movimentos nacionalistas que surgiam nas colônias. Em muitos casos a guerra de independência fora árdua e sangrenta, como na Argélia. Em outros casos, após a independência surgiam novas guerras de secessão, como no caso da Índia e do Paquistão, cujo conflito ainda é tenso. Em muitos outros Estados novos a disputa pela liderança ainda assola a estabilidade política, como em Ruanda. É preciso frisar, entretanto, que houve países destas regiões que superaram as adversidades e prosseguiram de forma a construírem um Estado forte. São exemplos Singapura, China, Coréia e Egito.

Os novos Estados tiverem de se firmar dentro de um contexto mundial bastante complicado. Na época da descolonização (décadas 1950 e 1960), o mundo estava divido entre leste e oeste, entre capitalismo e comunismo (SARAIVA 2007, P.197 $)^{18}$. Cada superpotência procurava aliciar novos membros para seus respectivos campos, não sendo possível aos novos Estados manterem-se distantes do conflito.

18 SARAIVA, JFS. Dois Gigantes e um Condomínio: da Guerra Fria à Coexistência Pacífica (1947 1968) in: SARAIVA, JFS (org). História das Relações Internacionais Contemporâneas: da Sociedade Internacional do Século XIX à era da Globalização. São Paulo: Ed. Saraiva, 2007. 247 páginas. 
Com a Europa já decidida, o campo de batalha da Guerra Fria foi levado para o hemisfério sul. Tanto o bloco capitalista quanto o socialista utilizavam-se de técnicas bastante persuasivas, tais como ajuda externa, investimentos, venda de armas e treinamento militar para atrair novos aliados (HELMAN e RATNER 1993, p.4) ${ }^{19}$. Quando um bloco apoiava o governo de fato, o outro apoiava a oposição, promovendo a proliferação de conflitos internos constantes e da desestruturação desses Estados. Muitos não chegaram a se formar propriamente dito, pela falta da estabilidade que impediu a construção das instituições políticas requeridas pelo Estado.

Devido à entrada constante de fluxos de capital, ao apoio político efetivo aos líderes que se mantinham aliados às superpotências, muitos dos governos que foram empossados com o apoio de um dos blocos foram por eles também sustentados. Dessa forma surgiram personalidades como Mobuto no Zaire e Suharto na Indonésia, personalidades fortes que eram mantidas no poder por serem aliadas, por cumprir com as linhas-guias das superpotências, mas ao mesmo tempo instalaram governos corruptos, autoritários, fortemente militarizados, com sistemáticas violações aos direitos humanos. Como conseqüência, a grande maioria desses novos Estados que foram cooptados para a Guerra Fria foram inundados com armas, empoderando tanto o governo como os atores não-estatais e tornando extremamente árdua a tarefa da formação do Estado nacional. Conflitos se prolongaram afetando sobretudo a população civil, estagnando o desenvolvimento econômico autônomo e impedindo a estabilidade política de se consolidar.

Com o final da Guerra Fria, a importância estratégica desses Estados deixou de existir. O desmoronamento do bloco socialista levou à introversão dos Estados que se formavam, desviando as preocupações de política externa para a afirmação de suas independências no sistema internacional. Recursos que antes eram utilizados para

19 Helman, G.B. \& Ratner (1993), S.R. Saving Failed States. Foreign Policy, No. 89 (winter) Páginas 3-20; Ver também: GHANI, A, LOCKHART, C. \& CARNAHAN (2006), M. An Agenda for State-Building in the Twenty-First Century. The Fletcher Forum of World Affairs, Vol 30: 1 (winter), páginas 101 a 126; SALAMÉ, Ghasan. As Guerras do pós-Guerra Fria. In: SMOUTS, Marie-Claude. As Novas Relações Internacionais: Práticas e Teorias. Brasília, Editora Universidade de Brasília: 2004. 408 páginas. 
manter os Estados aliados na disputa ideológica agora eram disputados pelas exrepúblicas soviéticas para sua própria agenda de reforma do Estado.

Do lado da superpotência que restou, os Estados Unidos, a agenda econômica visava afirmar a nova ordem mundial por meio de reformas liberalizantes que deveriam ser largamente adotadas não apenas pelos aliados durante a Guerra, mas por quem precisasse da ajuda das instituições financeiras internacionais. Procuravase assim, não apenas afirmar a hegemonia dos Estados Unidos, mas criar novos laços de dependência com relação à superpotência. A ajuda financeira continuou a existir, embora tenha sido bastante reduzida e cedida em troca da adoção das linhas-guias demandadas pelas instituições financeiras internacionais. Estas diretrizes, conhecidas como o consenso de Washington ${ }^{20}$, visavam criar estímulos à produção e à vantagem comparativa, que, por sua vez, traria o desenvolvimento econômico. O que elas implicavam de fato era a redução do peso Estatal na economia, com a redução do Estado como um todo. Todavia, a desordem dentro de alguns dos novos países instaurada pelos constantes conflitos internos já havia debilitado a formação do Estado. A adoção das medidas do FMI apenas agravou sua situação, tornando-os mais débeis que antes. Uma redução da esfera estatal apenas comprometeria mais ainda a situação frágil desses Estados, sendo, portanto, completamente inadequada para a situação as mudanças políticas e econômicas requeridas pelas instituições financeiras (GROS 1996, p.470) ${ }^{21}$. Questionava-se até a capacidade desses novos Estados de implementarem efetivamente em seu território essas diretrizes.

Muitos países, como por exemplo a Somália, a Indonésia, as Filipinas, viram a legitimidade de seus governantes erodida sem o apoio das superpotências. Sem a ajuda financeira que mantinham as elites no poder, a pobreza que já era enorme em muitos desses países, em especial na África, alastrou-se. Com isso vieram epidemias,

20 O termo foi criado em 1989 por economistas de instituições financeiras baseadas em Washington DC, tais como o FMI, Banco Mundial e o Departamento do Tesouro dos Estados Unidos e tornou-se política oficial do FMI em 1990 quando passou a ser receitado para promover o ajustamento macroeconômico dos países em desenvolvimento que encontravam-se em dificuldades. Seus princípios são: abertura comercial, privatização de empresas estatais, desregulação, combate à inflação (que se faz tanto com a abertura comercial, quanto com juros positivos, equilíbrio fiscal e queda de tributos, que requer queda de gastos), atração do IED, câmbio competitivo/de mercado (que na segunda metade da década de 1990 desemboca no câmbio flutuante.

21 GROS, Jean-Germain (1996). Towards a Taxonomy of Failed States in the New World Order:

Decaying Somalia, Liberia, Rwanda and Hainti. Third World Quarterly, Vol 17, nº 3, páginas 455-471. 
mais conflitos violentos, degradação do meio ambiente, condições cíclicas, intrinsecamente relacionadas que, sem serem apropriadamente dirigidas, aprofundaram a crise desses países (ONU 2004) ${ }^{22}$. A única justificativa para a pouca legitimidade dos governantes era a sua capacidade de trazer ajuda financeira para o país. Sem acesso aos recursos financeiros, sua autoridade fora questionada e desafiada, fragmentando o que existia de governo centralizado.

Durante o período do pós-Guerra Fria até os ataques de 11 de setembro de 2001 a comunidade internacional não dedicou a atenção devida à questão destes países, conhecidos como Estados Falidos. O princípio da não-intervenção em assuntos internos fora utilizado como forma de eximir uma atuação mais enérgica das Nações Unidas, embora excessões pontuais ocorressem, quando era de interesse direito das potências ocidentais, como por exemplo no Haiti, na Somália e em Ruanda (Operação Turquoise). O colapso do Estado era visto como uma conseqüência da guerra civil recorrente na África e em algumas partes da Ásia e da América Central, causada pela irresponsabilidade dos diferentes grupos opositores que não conseguiam chegar a uma solução para seus problemas (REUTER 1999) ${ }^{23}$.

Com os ataques de 11 de setembro, esta perspectiva fora radicalmente mudada. Os Estados falidos foram vistos como refúgios para grupos terroristas, proporcionando campos de treinamento e, devido à situação caótica intrínseca a eles, não haveria autoridade repressora para liquidar os grupos terroristas. De problema dos outros, os Estados Falidos passaram a ocupar um lugar de destaque na agenda de segurança mundial, impulsionado pela Guerra Contra o Terror do Presidente George W. Bush, devido à grande potencialidade de desestruturação política contra as nações desenvolvidas. Hoje há uma grande preocupação com os processos de State-

22 ORGANIZAÇÃO DAS NAÇÕES UNIDAS. A More Secure World. relatório apresentado na $59^{\mathrm{a}}$ Assembléia Geral das Nações Unidas em 2 de dezembro de 2004. 99 páginas.

23 Devido à natureza do direito internacional público, a cogência das normas e das convenções internacionais (incluído aí as resoluções do conselho de segurança das nações unidas) depende da vontade dos Estados em acatá-las. Isso não significa que a comunidade internacional está isenta de tomar medidas caso um país desrespeite a ordem internacional. Essas medidas, entretanto, estão restringidas ao âmbito internacional, não podendo a comunidade internacional intervir diretamente no Estado desrespeitador, pois isso seria uma violação do direito à soberania, abrindo graves precedentes para esse tipo de ação. Ver, por exemplo, REUTER, Paul. Introducción al Derecho de Los Tratados. Traducción de Eduardo L. Suárez. México, Universidad Nacional Aunónoma de México: 1999. 340 páginas. 
Building, ou seja, construção dos Estados, para que esses Estados falidos evoluam da fase atual para a de um Estado propriamente dito, reforçando assim a segurança coletiva mundial. Um Estado forte e democrático, de acordo com a National Strategy for Combating Terrorism (2003), impede a proliferação de grupos terroristas. Este ponto, entretanto, é bastante contestado (HEHIR 2007) ${ }^{24}$. A reconstrução desses Estados é um processo moroso, sem haver consenso na comunidade internacional acerca da melhor maneira de realizá-lo (GHANI, LOCKHART e CARNAHAN 2006).

No contexto atual, existe uma clivagem no sistema internacional. Existem Estados mais fortes, menos fortes e fracos. É importante manter este fato em mente pois a caracterização de um Estado como falido está relacionada também com a maneira como este Estado é observado pela sociedade internacional, sua relevância histórica, regional, política, quais recursos econômicos possui e que tipo de ajuda receberá e quão bem conseguirá resistir às pressões externas.

\section{2 - O que é um Estado Falido, um Quasi-Estado e um País Menos Avançado?}

Muitos dos novos Estados formados nas décadas de 1950 e 1960 como resultado dos processos de descolonização entraram em colapso e são considerados hoje como Estados Falidos, embora não haja consenso entre os estudiosos acerca da definição precisa do termo.

Helman e Ratner (1993) foram um dos primeiros acadêmicos a dirigirem-se sobre a questão dos Estados Falidos. Eles procuram demonstrar exemplos de Estados Falidos, embora não ofereçam uma definição precisa do termo. Para eles, há três grupos de Estado cuja sobrevivência está sob ameaça: o primeiro grupo, e o caso

24 Ver, por exemplo, HEHIR, Aidan (2007). The Myth of the Failed State and the War on Terror: A Challenge to the Conventional Wisdom. Journal of Intervention and Statebuilding, Vol. $1 \mathrm{n}^{\mathrm{o}} 3$ pp. 307-332. Neste Artigo Hehir compara o Failed State Index com o Foreign Terrorist Organization List, uma lista preparada pela chancelaria norte-americana. Interessantemente, Hehir quebra a idéia tradicional norte americana de que 'failed states are breeding grounds of international instability, violence and misery' (p. 311) ao constatar que as democracias desenvolvidas são as que mais oferecem oportunidades aos grupos terroristas para desenvolverem suas atividades devido à sua estrutura normativa e social, além do acesso à tecnologia e uma infraestrutura de comunicação vastamente desenvolvida. 
mais grave, são os Estados cujas "estruturas governamentais foram oprimidas pelas circunstâncias" (HELMAN e RATNER 1993). Exemplos dados pelos autores são a Bósnia e o Camboja. Ao segundo grupo, pertencem os países que estão em processo de falência, nos quais o colapso do Estado ainda não aconteceu, mas que pode ocorrer em um tempo próximo, como na Geórgia e na Etiópia. No terceiro grupo estão os países da ex-Iugoslávia e da União Soviética, cujo sucesso ainda estava longe de ser vislumbrado. Essa categorização de Helman e Ratner é bastante vaga. Eles não explicam, por exemplo, quais foram as circunstâncias de opressão do governo que levaram ao colapso do Estado. Foram elas endógenas ou exógenas? Qual a sua natureza? Essas circunstâncias são as mesmas para todos os Estados falidos? Falham também em explicar como seria o processo que leva à falência dos Estados.

Apesar de apontarem para diferentes estágios da falência, Helman e Ratner deixam a impressão de que há uma homogeneidade neste processo, como uma evolução de estágios que leva um Estado a falir. Essa visão, entretanto, pouco ajuda para a solução da questão dos Estados falidos. Isto porque a idéia de homogeneidade leva à crença de que uma única fórmula serve para todos os casos, o que não é verdade. As condições que levaram um Estado à falência e geral não são as mesmas para outro.

Mesmo havendo passado algum tempo a desde a publicação do artigo, ainda não se chegou a um consenso acerca da definição do termo Estado falido. Pelo contrário, outros termos com conotações semelhantes surgiram também: “collapsed states", "quasi-states" e o termo "Países menos desenvolvidos" cunhado pela ONU para países pobres que apresentam dificuldades para alcançar o desenvolvimento econômico. Faz-se necessário, portanto, fazer a distinção entre eles.

Os chamados collapsed states ou Estados que entraram em colapso são considerados como uma fase da falência, a mais grave, de acordo com Milliken e Krause (2003, p.19). Os collapsed states, portanto, estão configurados dentro dos parâmetros do Estado falido. Não são diferentes, apenas o aprofundamento de um processo de decadência, acompanhada da incapacidade do Estado de prover as 
funções mais básicas [que, na concepção dos autores, seria assegurar uma estrutura politico-jurídica para que a atividade econômica possa se desenvolver, além da promoção do bem-estar social (Welfare State)] (MILLIKEN e KRAUSE, p.9). Milliken e Krause (2003), apontam ainda para dois temas históricos que são particularmente relevantes para a análise dos Estados falidos e em colapso: a necessidade de um sistema político-legal estável para propiciar crescimento e desenvolvimento econômico e o surgimento do Estado do bem-estar social como uma forma eficaz para unir cidadãos aos seus Estados (MILLIKEN e KRAUSE 2003, p.8). Para estes teóricos, a primeira dimensão na qual o Estado falha economicamente é a instabilidade jurídica que afeta a acumulação de capital em todas as suas formas. A incapacidade de prover um ambiente juridicamente estável afeta todos os setores da sociedade, desincentivando a atividade econômica, aumentando a pobreza, a tensão, acirrando a divisão social. A incapacidade de prover atividades econômicas para seus cidadãos gera desconfiança no governo e sua conseqüente deslegitimação.

O Estado do bem-estar social procura trazer confortos à população: subsídios diretos e/ou indiretos, pagos com renda obtida interna ou externamente. Milliken e Krause lembram que as estruturas do bem-estar, nos Estados Falidos, servem mais como um centro legitimador do regime, criando vínculos de dependência entre os cidadãos e os Estados, a distribuição de recursos é bastante desigual, o que faz aumentar tensões entre diferentes grupos sociais. Para os autores, estes dois indicativos são especialmente importantes para a caracterização do Estado falido. Ambos indicativos dizem respeito ao relacionamento do Estado com a população, se proporciona ou não condições favoráveis para o desenvolvimento econômico e social. Para Milliken e Krause (2003), se o Estado não consegue proporcionar um mínimo de bem-estar para sua população, é porque o Estado faliu. O Estado, nesta situação, perdeu a legitimidade como organizador da política porque ao não proporcionar condições para o desenvolvimento econômico, não consegue proporcionar as condições mínimas para o desempenho político dos diversos grupos sociais. $\mathrm{O}$ perigo dessa situação é o transbordamento das tensões/ameaças/instabilidades para países vizinhos, incorrendo no risco de causar 
instabilidade generalizada.

Bilgin e Morton (2002) já classificam os collapsed states como "Estados confrontados por uma situação na qual a estrutura, a autoridade (o poder legítimo), a lei e a ordem política foram derrubados e que devem ser reconstituídos de alguma forma, velha ou nova" ${ }^{25}$. Apesar da terminologia diferente e do acréscimo de alguns aspectos, para estes autores, os collapsed states também são partes de um mesmo processo de falência. A fraqueza destes Estados ocorre pelo subdesenvolvimento das estruturas institucionais, que não são capazes de conter e direcionar as tensões políticas, nem de dirigir a economia. Para estes autores, entretanto, isto não basta para explicar a fraqueza desses Estados. É preciso também levar em consideração o passado colonial e o posicionamento destes países diante das estruturas políticoeconômicas globais (BILGIN e MORTON 2002 p. 66). Se não, corre-se o risco de incorrer na falácia de que a falência é uma implosão, um processo que ocorre por características internas atuais somente sem influência do passado ou do contexto global. Bilgin e Morton dão um importante passo além de Milliken e Krause ao juntar as causas exógenas à incapacidade do Estado em cumprir com sua função organizadora para explicar o motivo da falência.

De acordo com Di John (2008), a falência do Estado pode ocorrer em várias dimensões: na segurança, no desenvolvimento econômico, na distribuição de renda, não necessariamente ocorrendo em todas ao mesmo tempo. Di John complementa a definição de Rotberg (2002, apud DI JOHN 2008 p. 5) para quem os Estados entram em falência por não conseguirem prover bens políticos à sua população, perdendo assim sua legitimidade. Ou seja, o Estado pode falir em certos aspectos mas não completamente. A falência pode ocorrer em apenas algumas instituições Estatais, mas não necessariamente em todas. Di John (2008 p.5) aponta o exemplo da Colômbia, que perdeu o controle sobre partes de seu território, mas onde ainda mantém controle possui também presença forte. Esta falência por setores não se relaciona diretamente

25 BILGIN, P \& MORTON, A.D. (2002). Historicizing Representations of 'Failed States': Beyond the Cold-War Annexation of the Social Sciences? Third World Quarterly, Vol. 23, $\mathrm{n}^{\circ} 1$ (fevereiro). pp. 55-80. 
com os motivos apontados por Milliken e Krause (instabilidade jurídica e ausência de bem-estar social) e não é tão geral como aponta Bilgin e Morton, mas sim, implica na disputa entre atores não-estatais e o próprio Estado. A falência do Estado pode ocorrer por fatores exógenos ao Estado.

Nas três propostas de definição do Estado falido temos três disfunções do Estado. No caso de Milliken e Krause, o Estado é entendido como um provedor, o Estado do bem-estar social. Faz parte das funções do Estado subsidiar o acesso de sua populações a bens materiais e imateriais e promover o acúmulo e investimento de capitais. O Estado organiza as relações sociais, políticas e econômicas. No momento em que não consegue mais cumprir com sua função organizadora, torna-se disfuncional e entra em falência. O Estado de Bilgin e Morton não conseguiu construir suas instituições fortes o suficiente para funcionarem. O que eles acrescentam é que não são apenas fatores internos que impedem a construção dessas instituições, mas o histórico do país e o contexto político-econômico regional e global. A interferência externa solapa as condições de construção Estatal como, por exemplo, no colonialismo e, mais recentemente, nas intervenções diretas e indiretas. O Estado de Di John não conseguiu se organizar, e, portanto, não constitui um centro organizador da política nacional. Ele possui as instituições mas elas não são fortes o suficiente para atuarem como deviam e organizar a sociedade.

O problema dessas análises é que os autores deixam de procurar as condições de existência do Estado, apenas olhando caso a caso na procura de razões materiais para a falência: seja a instabilidade jurídica, a interferência externa, a corrupção, a maldição das riquezas naturais, os constantes conflitos internos. Identificam que existe algo de errado, mas como consideram a existência do Estado como algo dado e necessário, a não percebem que o próprio problema da delimitação das características do Estado, torna difícil a caracterização do Estado Falido. Onde o Estado começa e termina, o que o compõe, sua natureza são dados essenciais para se discutir porque faliu. Ou o Estado existe e, portanto, cumpre com os critérios de identificação, ou existe alguma outra forma de organizador político. Talvez chamar os Estados falidos 
de Estados seja parte da dificuldade de se achar soluções para seus problemas. Isto porque se o Estado falido não possui as características que o qualificariam como Estado, as soluções encontradas para consertar o Estado falido necessariamente serão ineficientes. A ausência de um Estado é consertada com a construção do Estado e não com medidas para corrigir ineficiências de instituições que não existem.

Cabe buscar as raízes históricas e institucionais para esta falha. Para Milliken e Krause (2003) durante o processo de descolonização, o Estado era visto como a única forma possível de proporcionar governança. Muitos dos novos Estados criados neste processo, apesar de não possuírem critérios do Estado de acordo com o direito internacional da época, foram reconhecidos como Estados independentes. A formação incompleta destes Estados levou ao estabelecimento dos quasi-states que, na definição de R. Jackson:

[quasi-states]...disclosed limited empirical statehood: their populations do not enjoy many of the advantages traditionally associated with independent statehood. Their governments are often deficient in the political will, institutional authority, and organized power to protect human rights or provide socio-economic welfare. The concrete benefits which have historically justified the undeniable burden of sovereign statehood are often limited to fairly narrow elites and not yet extended to the citizenry at large (JACKSON 1990 p.21) ${ }^{26}$.

Os quasi-states não se formaram por completo, e possuem capacidades limitadas. Não conseguem impor leis ou obter legitimidade, não criam condições para o desenvolvimento político e econômico nacionais porque não possuem as instituições para tanto. A diferença significativa entre os quasi-Estados e os Estados

26 JACKSON, Robert. Quasi-states: Soverignty, International Relations and the Third World. Cambridge: Cambridge Studies in International Relations, 1990. 255 páginas.

“... possuíam condições de soberania limitadas: suas populações não aproveitavam das vantagens tradicionalmente associadas com um Estado independente. Seus governos são frequentemente definicentes em vontade política, autoridade institucional, e poder organizado para proteger os direitos humanos ou fornecer o bem-estar sócio-econômico. Os benefícios concretos que historicamente justificou a carga inegável de um Estado soberano são frequentemente limitados às pequenas elites e ainda não foram estendidos para os cidadãos em geral." 
falidos é que o segundo assume que a criação do Estado foi completada e posteriormente este Estado entrou em decadência. Para o primeiro, o Estado ainda está em construção, não possuindo ainda todos os instrumentos necessários para seu funcionamento adequado. Em muitos dos casos, a imposição da forma Estatal não foi acompanhada das mudanças sociais e institucionais requeridas. O quasi-Estado é um processo inacabado e imperfeito, necessitando de constantes adaptações para se encaixar no regime de Estados da sociedade internacional. Em muitos dos casos, as instituições estatais existem apenas formalmente, sem ser capaz de cumprir com suas funções. Os quasi-Estados nunca foram Estados de fato.

Em seu artigo de 2005, Rosa Brooks aprofunda a questão da construção estatal após a colonização. Suas definições para o Estado falido são: "Estados incapazes de proteger seus cidadãos dentro de seu território" e " países cujos governos enfraqueceram a tal ponto que não conseguem mais prover bens públicos, tais como integridade territorial, infraestrutura econômica e segurança física $(\text { BROOKS 2005) })^{27}$. Suas definições são genéricas o suficiente para abarcar a maioria dos Estados hoje existentes. Entretanto, diferentemente de Jackson, Brooks aborda a questão pelo lado jurídico: os Estados recém tornados independentes apenas apresentavam as características formais legais sem possuírem de fato os atributos institucionais estatais. Estes Estados foram construídos de fora para dentro, primeiro com o colonialismo, que partilhou suas fronteiras e população e implantou uma estrutura política e econômica para atender às necessidades da metrópole sem levar em consideração as necessidades locais. Depois, com a independência durante a Guerra Fria, que condicionou a ajuda ao desenvolvimento a alianças estratégicas. A constante interferência na autodeterminação destes Estados desfiguraram a sua formação, fazendo-os buscar conformidade com o sistema internacional antes de buscar a conformidade interna, entre os diferentes grupos sociais (BROOKS 2005). Brooks (2005) aponta ainda para as semelhanças entre o Estado falido e a sociedade internacional: a falta de soberania, de governo, de hard laws, indicam a inexistência do Estado, não a falência ou meia construção de um. A sociedade internacional nunca foi considerada um Estado pelos mesmos fatores que caracterizam o Estado falido.

27 BROOKS, R. E. (2005). Failed State or the State as Failure? The Chicago Law Review, Vol. 72, No 4 (fall), páginas 1159 a 1196. 
Além destas duas definições, foi criado pela ONU, durante a década de 1960 um grupo chamado de Países Menos Avançados (PMAs em inglês: Least Developed Countries - LDCs), que representam o segmento mais pobre e fraco da comunidade internacional (UN-OHRLLS 2010a) ${ }^{28}$. Eles são caracterizados pela pobreza extrema, fraqueza estrutural de suas economias, falta de infra-estrutura, suscetibilidade a choques externos, a desastres naturais e feitos por homens (conflitos), e a epidemias (tais como de AIDS e malária). Muitos desses países possuem impedimentos geográficos, ora pelo fato de não possuírem fronteiras marítimas, ora por serem pequenas ilhas distantes de grandes centros comerciais. $O$ fato é que $o$ desenvolvimento econômico destas países é bastante precário, tornando-os extremamente dependentes de ajuda externa, tais como ajuda humanitária, investimentos externos diretos e indiretos. De acordo com a ONU, existem 50 países nesta situação atualmente, a grande maioria deles na África (UN-OHRLLS 2010a).

Os países menos desenvolvidos compõem uma classificação oficial e reconhecida pela sociedade internacional de países com problemas de desenvolvimento. Esta classificação preocupa-se mais com as condições para o desenvolvimento econômico que deverá ser acompanhado do desenvolvimento político, mas implicitamente acrescenta que sem o desenvolvimento econômico destas nações, não haverá o desenvolvimento social e político.

\section{3 - Como medir a falência ou o grau de construção do Estado?}

Para o relatório de 2009, o Comitê para o Políticas de Desenvolvimento adotou 3 critérios para a identificação dos Países Menos Avançados:

- baixa renda, com base em um período de três anos no qual a média da renda nacional per capita esteja abaixo de US\$ 905 (devendo subir para US\$ 1086 para o país deixar de ser considerado como PMA);

28 UN-OHRLLS. 2010a Disponível em: $<$ http://www.unohrlls.org/en/ldc/25/>. Acesso em $13 \mathrm{~d}$ março de 2010 
- capital humano, com base nos indicadores de nutrição (percentagem da população subnutrida), saúde (mortalidade infantil), educação (taxa de escolarização no nível secundário) e média de alfabetização adulta.

- Vulnerabilidade econômica, envolvendo o Índice de Vulnerabilidade Econômica (EVI em inglês) que tem como base o tamanho da população; o isolamento do país em relação à economia internacional; a concentração das exportações de mercadorias; participação da agricultura, silvicultura e pesca no produto interno bruto; desabrigados devido a desastres naturais; instabilidade da produção agrícola e a instabilidade da exportação de bens e serviços (UN-OHRLLS 2010).

Um país precisa preencher todos os critérios para ser considerado PMA. As economias grandes são excluídas desta categorias, devendo a população ser menor que 75 milhões. Para ser desconsiderado como PMA ou, na terminologia da ONU, evoluir, um país deve alcançar níveis mínimos em pelo menos 2 dos 3 critérios mencionados, ou seu produto interno bruto per capita deve ultrapassar em pelo menos 2 vezes o limite (de US \$1086), sendo que a probabilidade de manutenção deste novo patamar seja considerada alta ${ }^{29}$.

$\mathrm{Na}$ ausência de uma definição única para os Estados Falidos e de outra alternativa de mensuração da falência, o Fund For Peace, um thinktank baseado em Washington D.C. criou o Failed State Index (FSI). Por meio deste índice, criado em 2005 e publicado anualmente pela revista Foreign Policy, é possível criar um panorama da situação interna de diversos Estados mundo afora e quais deficiências podem levar à sua falência. Justamente pelo fato de indicar as deficiências específicas, não há um consenso acerca da eficácia do FSI, mas, na ausência de outros indicadores, este se torna uma ferramenta no estudo dos Estados Falidos.

29 Estes critérios são baseados em dados fornecidos pelo Banco Mundial (Development Research Group, Human Development Network, World Development Indicators database, )pelas diferentes divisões das nações unidas (Population Division, FAO, WHO, UNICEF, UNESCO, UNAIDS), ITU, FMI, BIRD. UN \& WORLD BANK. Measuring Progress in Least Developed Countries. Documento apresentado na $61^{\mathrm{a}}$ Assembléia Geral das Nações Unidas em Setembro de 2006. Disponível em: <http://www.unohrlls.org/UserFiles/File/Publications/progress\%20in\%20LDCs.pdf $>$. Acessado em 13 de março de 2010. 
O Failed State Index possui doze indicadores de vulnerabilidade ao colapso ou ao conflito: pressão demográfica, movimento de refugiados e população deslocada internamente, legado de grupos que buscam vingança, fugas crônicas e sistêmicas de seres humanos, desenvolvimento econômico desigual dentro de grupos distintos, crise econômica grave, criminalização e/ou deslegitimação do Estado, deterioração progressiva de serviços públicos, violação contínua dos direitos humanos, aparelhagem de segurança que supõe um "Estado dentro do Estado", crescimento da elites faccionárias e intervenção de outros Estados ou fatores externos (FUND FOR PEACE 2009a) ${ }^{30}$. Estes critérios, entretanto, por si só, não são suficientes para qualificar o Estado como Falido. É necessário a combinação dos diversos indicadores em diversos graus para que haja a falência. $\mathrm{O}$ que o índice busca avaliar, no entanto, é a probabilidade de ocorrência de conflitos que possivelmente desestruturem o Estado a tal ponto de provocar seu desmoronamento e, consequentemente, o sofrimento de sua população. A lógica que se segue é a de que se há instabilidade generalizada interna decorrente de conflitos internos, o Estado está falido por não conseguir prover a estabilidade, a segurança física e jurídica e, consequentemente, o bem-estar de sua população. Por este mesmo motivo o índice é bastante controverso. A grande crítica para o Failed State Index é a arbitrariedade de seus critérios e a conseqüente generalização das causas da falência para contextos bem específicos $(\text { AKPAN 2008) })^{31}$.

A ferramenta utilizada para tal mensuração é conhecida como CAST, Conflit Assesment Tool, criada pelo próprio Fund for Peace. Ela avalia a intensidade da ocorrência dos doze fatores supramencionados com base em diversos estudos de diversas fontes (sendo estes de governos, de instituições internacionais, de organizações não-governamentais, etc.), que buscam avaliar as condições para a implosão dos Estados, contando fatores internos e externos. Busca-se, primeiro, preparar a avaliação dos conflitos. Isto é feito por meio de coleta de dados relevantes, a formação de uma linha de tempo completa dos eventos e a escolha de datas-chave

30 FUND FOR PEACE. Failed State Index. 2009a. Disponínvel em:

$<$ http://www.fundforpeace.org/cast/index.php?

option $=$ com content \&task=view\&id=14\&Itemid=30>. Acessado em 13 de março de 2010.

31 AKPAN, Felix. Road Map to Failed State: The Nexus Between Bad Governance and Failed State.

Pakistan Journal of Social Sciences, vol. 5. nº 9, 2008, pág. 945-952 
para a avaliação de um padrão pontual dos conflitos. Em segundo lugar, avalia-se individualmente cada um dos doze indicadores supramencionados, considerando em cada caso as especificidades de cada país e de cada indicador. Eles medem os seguintes elementos-chave: social, econômico, político e militar de cada país, de mês a mês. Para cada indicador é dado uma nota entre 0 e 10 , sendo 0 a menor intensidade de ocorrência e 10 a maior intensidade. O somatório das 12 notas do mês criará um pontos-padrão, que, agregado a outros pontos-padrões de períodos próximos, criarão um padrão agregado de tendência dos conflitos. Dessa forma, é possível avaliar a evolução ou involução da situação de cada Estado. Em terceiro lugar, são avaliados os cinco elementos principais para a sustentação do Estado: 1) a existência de uma força policial doméstica e de um sistema penal competentes, 2) serviço civil funcionando e burocracia profissional eficiente, 3) sistema judicial competente que funciona sobre o rule of law, 4) forças armadas profissionais e disciplinadas, que respondem a um governo civil e 5) liderança executiva e legislativa fortes, capazes de proporcionar governança nacional. Em quarto lugar, são identificados os fatores não-antecipados que atuam como catalisadores acelerando ou desacelerando o risco imediato de conflito: surpresas, gatilhos, idiossincrasias, temperamentos nacionais e empecilhos. O quinto e último passo é construir um mapa de conflitos, mostrando o caminho dos conflitos para cada data significativa, o que proporciona a visualização da possível resolução ou intensificação do conflito (FUND FOR PEACE 2009a).

No entanto, é preciso olhar com certa cautela o índice, pois este foco na segurança humana transforma Estados que possuem controle efetivo sobre suas fronteiras e populações em Estados falidos. Um exemplo constante nos índices anteriores é a presença da Coréia do Norte entre os 'top' 20 Estados Falidos (MONTEIRO 2006, p.40) ${ }^{32}$.

O mérito do Failed State Index está em agregar de maneira extensa diversas acepções comuns de Estados Falidos. Nele encaixam-se definições como as de

32 MONTEIRO, Leandro N. O Conceito de Estados Fracassados nas Relações Internacionais: Origens, Definições e Implicações Teóricas. Dissertação de mestrado (134p.) Programa de PósGraduação em Relações Internacionais, Universidade Paulista "Júlio de Mesquita Filho", Universidade de Campinas e Pontifícia Universidade Católica de São Paulo. São Paulo, 2006. 
Milliken e Krause, de Bilgin e Morton mas com um foco diferente. Os quatro autores mencionados procuram estabelecer as razões institucionais para a falência do Estado, os fatores que o tornam desfuncional, e o FSI aponta para uma resposta: os conflitos internos e a incapacidade de o Estado responder propriamente a eles como a causa da falência. De certa forma, esta é uma lógica circular, pois se os conflitos causam a falência, e o aprofundamento desta causa mais conflitos, a única esperança repousa na cessação destes conflitos. Entretanto, seguindo este raciocínio, devido à incapacidade organizacional do Estado, ele apenas conseguirá cessar a turbulência interna com ajuda externa. E esta lógica torna-se extremamente perigosa por dar margem a intervenção humanitária, ou seja, a intervenção externa para "salvar a população de seu próprio Estado" (GÓIS E BARROS-PLATIAU 2004) ${ }^{33}$. Este tipo de intervenção é particularmente perigosa pois ocorre sem a autorização do Estado, ferindo os princípios da soberania e da auto-determinação dos povos, debilitando ainda mais o processo de construção do Estado.

Ainda não foi desenvolvido um método de medição para os quasi-Estados. No entanto, é possível comparar suas características com a dos Países Menos Avançados e dos Estados Falidos (mais precisamente, o FSI) para termos uma noção melhor das diferenças entre cada um deles:

\begin{tabular}{|c|c|c|c|}
\hline & Quasi-Estados & PMAs & FSI \\
\hline $\begin{array}{l}\text { Instabilidade } \\
\text { Social }\end{array}$ & Conflitos internos; & $\begin{array}{l}\text { Baixo nível de } \\
\text { desenvolvimento do } \\
\text { capital humano com } \\
\text { base em: } \\
\text { - percentagem de } \\
\text { população } \\
\text { desnutrida; } \\
-\quad \text { mortalidade } \\
\text { infantil; } \\
-\quad \text { taxa } \\
\text { escolarização de no }\end{array}$ & 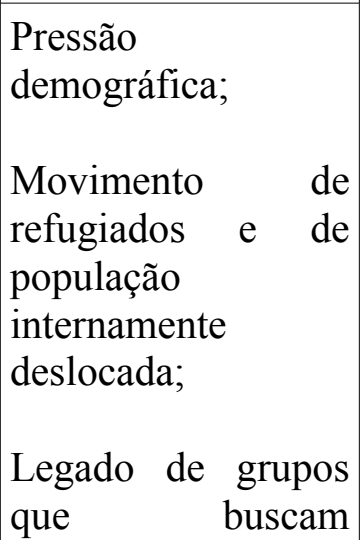 \\
\hline
\end{tabular}

33 GÓIS A. C. L. E BARROS-PLATIAU, A. F. Direito Internacional e Globalização Face às Questões de Direitos Humanos. In: RIBEIRO, M. de F. e Valério de Oliveira Mazzuoli (coords) Direito Internacional dos Direitos Humanos: estudos em homenagem à professora Flávia Piovesan. Curitiba: Juruá, 2004, 432p, pg. 57 a 71. 


\begin{tabular}{|c|c|c|c|}
\hline & & $\begin{array}{l}\text { nível secundário; } \\
-\quad \text { média de } \\
\text { alfabetização } \\
\text { adulta; }\end{array}$ & $\begin{array}{l}\text { vingança; } \\
\begin{array}{l}\text { Fugas crônicas e } \\
\text { sistêmicas; }\end{array}\end{array}$ \\
\hline $\begin{array}{l}\text { Instabilidade } \\
\text { Econômica }\end{array}$ & $\begin{array}{l}\text { Baixo crescimento } \\
\text { econômico }\end{array}$ & $\begin{array}{l}\text { Baixa renda per } \\
\text { capita nacional sem } \\
\text { modificação da } \\
\text { situação durante } 3 \\
\text { anos; } \\
\text { Vulnerabilidade } \\
\text { econômica causada } \\
\text { por: } \\
\text { - o isolamento do } \\
\text { país em relação à } \\
\text { economia } \\
\text { internacional; } \\
\text { - a concentração } \\
\text { das exportações de } \\
\text { mercadorias; } \\
\text { - a participação da } \\
\text { agricultura, } \\
\text { silvicultura e pesca } \\
\text { no produto interno } \\
\text { bruto; } \\
\text { - a instabilidade da } \\
\text { produção agrícola e } \\
\text { a instabilidade da } \\
\text { exportação de bens } \\
\text { e serviços. } \\
\text { - o tamanho da } \\
\text { população; } \\
\text { - os desabrigados } \\
\text { devido a desastres } \\
\text { naturais; }\end{array}$ & $\begin{array}{l}\text { - Desenvolvimento } \\
\text { econômico desigual } \\
\text { em meio a grupos } \\
\text { sociais distintos; } \\
\text { - Crise econômica } \\
\text { grave }\end{array}$ \\
\hline $\begin{array}{l}\text { Instabilidade } \\
\text { Política/ } \\
\text { Institucional }\end{array}$ & $\begin{array}{l}\text { Baixa } \\
\text { institucionalização } \\
\text { do Estado: } \\
\text { - Ausência de } \\
\text { autoridade política, } \\
\text { - Ausência de } \\
\text { legitimidade do } \\
\text { governo; } \\
\text { - Ausência de um }\end{array}$ & & $\begin{array}{lr}\text { Suspensão } & \text { ou } \\
\text { aplicação } & \text { arbitrária } \\
\text { da lei e } & \text { violação } \\
\text { dos } & \text { direitos } \\
\text { humanos; } & \\
& \\
\text { Criminalização e/ou } \\
\text { deslegitimação do } \\
\text { Estado; }\end{array}$ \\
\hline
\end{tabular}




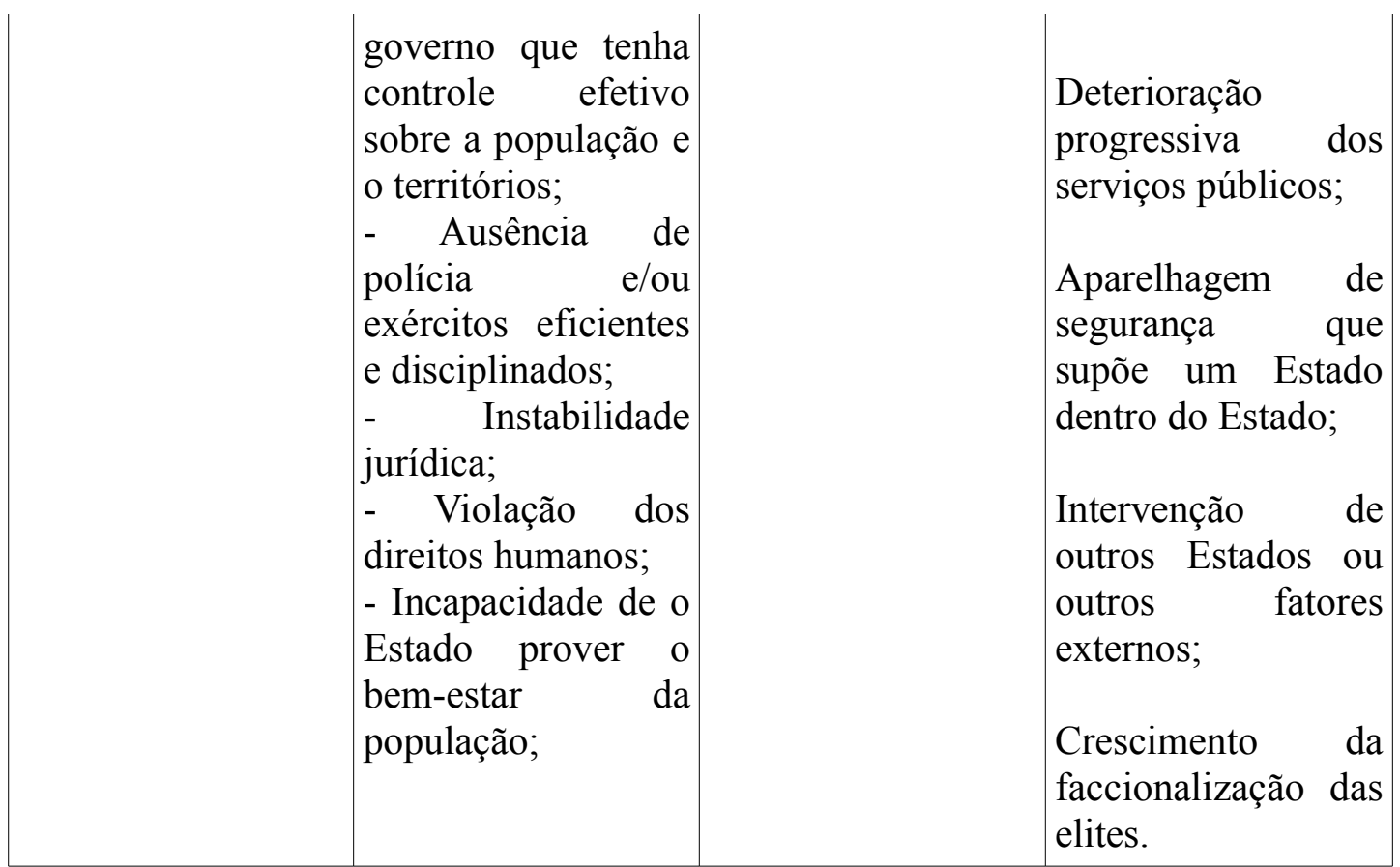

tabela 1: Comparação entre quasi-Estados, Países Menos Avançados e o Failed State Index.

Pela tabela fica mais fácil compreender a dimensão de cada termo. O quasiEstado concentra-se na não-formação na prática do Estado. A ausência de uma estaticidade empírica (empirical statehood), ou seja a existência das instituições que caracterizam o Estado como tal (JACKSON e ROSBERG 1982 p.2) ${ }^{34}$, é o que confirma a situação do quasi-Estado. Este não é um Estado per se, mas afirmou assim e foi considerado como tal para, perante a comunidade internacional, tornar-se independente e afirmar a soberania sobre um território determinado. Entretanto, a ausência das características estatais tornam o exercício da governança impossível.

No caso dos Países Menos Avançados, o que se vê é a concentração sobre os fatores de instabilidade econômica. A baixa renda per capita associada à grande vulnerabilidade econômica e baixo investimento no capital humano são elementos que limitam o desenvolvimento econômico do país e, portanto, o desenvolvimento político do Estado. O que podemos deduzir desta terminologia é que limitações no desenvolvimento econômico levam a limitações no desenvolvimento político. Por conseguinte, classificação como PMA não avalia as condições de existência do Estado, mas sim o desenvolvimento econômico do determinado país. Apesar de os 
PMAs terem um foco econômico, seus critérios podem nos dizer um pouco acerca do andamento do Estado: O baixo nível de desenvolvimento do capital humano é resultado de poucos investimentos governamentais em sua população. A má distribuição de renda e o baixo acesso à educação são indicativos de um Estado negligente e despreocupado com o futuro, com o desenvolvimento da sociedade com um todo. O baixo índice do crescimento econômico implica de novo em poucos investimentos públicos, seja nas condições da produção (infra-estrutura, incentivos econômicos, baixo uso de tecnologias disponíveis, baixa diversidade de produtos de exportação, predominância da agricultura de subsistência), vulnerabilidade grande a catástrofes naturais e humanas) aumentam a vulnerabilidade econômica do Estado e se não direcionadas, aprofundam a crise interna. Estes elementos apontam para um Estado fraco no qual grande parte da população é excluída de seus desígnios. Com uma população pouco satisfeita com a atuação de seus governantes, a provável ocorrência de conflitos internos é bastante alta, como também a instabilidade política.

Apesar de apontar para estas dificuldades, os PMAs não explicita quais falhas institucionais levam a esta situação. Deixa também de avaliar o impacto externo nas ordenanças internas. A ausência de menções a fatores sociais/políticos/institucionais na classificação dos PMAs não permite ter uma idéia das condições de existência em um Estado específico. Isto o torna, uma ferramenta complementar na análise dos Estados falidos e dos quasi-Estados, não uma ferramenta em si.

No caso dos critérios do Failed State Index, o já mencionado problema do enviesamento pela segurança humana limita a percepção acerca do desenvolvimento das instituições políticas. Ao olhar o índice de 2009, percebe-se que dos 177 Estados avaliados, 131 ou faliram ou estão sob o risco de falir (nesta categoria está incluída o Brasil). Em 2008 eram 127 países nesta posição. Em 2007, 129. Esta divisão segue assim desde o início do índice, em 2005. Ou seja, a maior parte do mundo, a maioria dos Estados estão falindo pelos critérios do FSI. Ao optar por critérios que identifiquem como anda a segurança humana nos diversos Estados, o FSI apenas reforça os ditos "valores universais": Estado de direito, direitos humanos e democracia. O Estado que não cumpre com estes valores é considerado falido ou em 
processo de falência. E a "cura" é simples: o respeito aos valores. Não é à toa que, ao se observar o mapa traçado pelo FSI, as únicas regiões que não correm risco de falência são a Europa, a América do Norte e a Oceania, bastiões destes valores.

Apesar de, teoricamente, buscarem dar indícios de porque o Estado deu errado em diversas regiões do mundo, cada termo assinala para um aspecto diferente. A incapacidade de o Estado realizar suas tarefas é a razão da desorganização da sociedade, e, portanto, o motivo pelo qual o Estado desmorona. É preciso, no entanto, novamente afirmar a diferença entre um Estado formado e um quasi-Estado. A condenação de um Estado em formação como experiência fracassada possui repercussões enormes quanto à atitude de outros Estados, desde a tutela até a intervenção, que interrompem o processo de diferenciação social interna, formação Estatal, o exercício da soberania e a própria definição como Estado. 


\section{3 - CONSIDERAÇÕES COM A AJUDA DA ERITRÉIA}

Como já visto, existem duas nomenclaturas diferentes para países em situações semelhantes: Estados Falidos e quasi-Estados. Cada uma possui critérios de classificação próprios, embora no caso dos Estados Falidos não haja um consenso largo acerca de uma única definição. Pretendo, neste capítulo, fazer uma comparação entre estes dois conceitos com base em um país específico: Eritréia.

Escolhi a Eritréia por ser um país relativamente novo (obteve sua independência da Etiópia em 1993). Apesar de estar localizado no Chifre da África e ser vizinho do Sudão, de Djibouti, da Etiópia, possui fronteira marítima com o Yemen o país não chama tanta atenção da comunidade internacional. A Eritréia possui problemas fronteiriços com basicamente todos os seus vizinhos, que resultaram em explosões de conflitos armados durante a década de 1990.

A história da libertação da Eritréia é bastante diferente da história de outros países africanos. Os rebeldes eram, em muitos casos, bem vistos pela população e, ao invés de saquear recursos escassos de pobres camponeses, dividiam suas rações com eles. Em meio aos conflitos era possível ver hospitais e escolas funcionando, cumprindo suas funções, embora precariamente (DORMAN 2003, p.3) ( $^{35}$ O movimento separatista pregava a igualdade dos cidadãos, sem distinção étnica ou religiosa. Como um país que aparentava ser tão promissor é hoje conhecido como falido?

\section{1 - Contexto Político-econômico Eritreu:}

No século XIX, a Itália invadiu a região que hoje corresponde à Eritréia, e transformou-a numa colônia, com as fronteiras atuais do país. Durante a Segunda Guerra Mundial, forças britânicas expulsaram a ocupação italiana, assumindo a administração da colônia sob mandato da ONU até 1951, quando foi decidido, pela

35 DORMAN, Sarah Rich. Eritrea's Nation and State-building: Re-assessing the impact of the struggle. In: Conference on Globalisation and Self-Determination. Working Paper Number 105 London, 4 de abril de 2003. 
resolução 390(A), devido a pressões das potências ocidentais, sua união à Etiópia como parte de um federação. Após o cancelamento da federação pelo imperador etíope, transformando a Eritréia numa província, movimentos separatistas formaramse no início da década de 1960, resultando na guerra de secessão que durou 30 anos.

A luta pela independência da Etiópia teve inicialmente uma grande frente de resistência: a Frente pela Libertação da Eritréia (FLE), formada por líderes islâmicos e conservadores, com apoio da Liga Árabe. A FLE possuía divisões internas baseadas na religião, ideologia, etnia, clã e, às vezes, personalidades, que serviram como fatores desintegradores do movimento. Posteriormente, a partir de desentendimentos internos da frente, diversos outros movimentos rivais surgiram. $\mathrm{O}$ mais significativo foi a Frente Popular pela Libertação da Eritréia (FPLE), que seguia as ideologias socialistas (seus líderes foram educados na China) e buscava criar um movimento que representasse o povo eritreu, unindo cristão, muçulmanos, sem divisão de gênero, religião ou etnia.

A FPLE ganhou significativo apoio interno e, posteriormente, a luta pela independência em 1991. Em 1993 foi realizado um referendo sobre a independência ou não da Eritréia. Com a vitória esmagadora do sim, a independência foi formalizada. Foi estabelecido um governo provisório pela FPLE. O líder da FPLE, Isaias Afewerki foi declarado o primeiro presidente provisório e a FPLE foi transformada em partido político e renomeada "Frente Popular para a Democracia e Justiça" (FPDJ). Foi decidido que em um período de quatro anos o governo provisório seria responsável pela convocação de uma assembléia nacional para a redação e instauração de uma constituição, pelo preparo de leis para partidos políticos e a realização de eleições gerais. Em 1997 a Constituição da Eritréia foi promulgada, porém com guerra sobre demarcação de fronteiras com a Etiópia no ano seguinte, que durou até 2000, as eleições foram adiadas até que as fronteiras com a Etiópia sejam estabelecidas. A Eritréia possui o mesmo presidente e membros do legislativo desde então (LIBRARY OF CONGRESS COUNTRY PROFILE 2010) ${ }^{36}$.

O governo provisório teve de construir as instituições estatais do nada. A

36 LIBRARY OF CONGRESS COUNTRY PROFILE, Washington D.C. Disponível em: $<$ http://lcweb2.loc.gov/frd/cs/profiles/Eritrea.pdf> $>$. Acessado em 15 de março de 2010. 
burocracia civil é pequena e fraca (FUND FOR PEACE COUNTRY PROFILE $2010)^{37}$. Apesar de a constituição prever diversos partidos políticos, o congelamento por tempo indefinido da situação provisória permite apenas a existência de um único partido, a FPDJ. O governo autoritário tem tomado medidas que reforçam sua posição, tais como o fechamento de todas as imprensas escritas privadas, o encarceramento de opositores políticos, a proibição de outras religiões que não o cristianismo ou o islã (LIBRARY OF CONGRESS COUNTRY PROFILE 2010). As violações aos direitos humanos são recorrentes. Em 2001 foi iniciado um movimento reformista que buscava implantar a constituição de 1998. Como resposta, o governo prendeu diversos ativistas, jornalistas e até o presidente da Alta Corte (DORMAN, 2003, p.12). As difíceis relações com os vizinhos (disputas fronteiriças, acusações de interferência em conflitos internos por parte do Sudão e da Somália) e com as potências ocidentais, em particular com os Estados Unidos, tornam a Eritréia cada vez mais isolada na comunidade internacional.

De acordo com o Fund for Peace (2009b), as pressões demográficas na Eritréia vem aumentando nos últimos anos devido a um alto crescimento populacional, com $43 \%$ da população abaixo dos 15 anos. A escassez de alimentos é generalizada. Desde 1998, o número de refugiados internos e externos cresceu. Pessoas fogem da fome, da violência e do serviço militar. O serviço militar foi tornado obrigatório para todos, homens e mulheres. Por causa da disputa fronteiriça com a Etiópia, o governo iniciou recrutamento contínuo com tempo ilimitado de serviço, sob o risco de multa e prisão de parentes que esconderem o(a) recruta. Por causa destes fatores, o ressentimento da população em relação ao governo instaurado tem aumentado.

Apesar da grande militarização da sociedade, a segurança ainda é um problema grave. Isto porque o governo utiliza de seus soldados para intimidar grupos sociais não-coniventes com suas políticas. A concentração de poder entre o presidente e seus aliados indica a alta faccionalização das elites. $\mathrm{O}$ aumento das tensões com seus vizinhos aumentam o risco de interferência externa na vida nacional (FUND

37 FUND FOR PEACE. Eritrea counry Profile, 2009b Dispoível em:

$<$ http://www.fundforpeace.org/web/index.php?

option $=$ com_content\&task=view\&id=396\&Itemid=555 $>$ Acessado em 15 de março de 2010. 
FOR PEACE 2009b).

A qualidade dos serviços públicos tem piorado desde 2007. Apenas 74\% da população urbana e $54 \%$ da população rural possuem água limpa. A percentagem da população que tem acesso ao saneamento básico é ainda menor: 14\% nas áreas urbanas e 3\% nas áreas rurais, o que aumento o risco de infecções e epidemias. A educação não é compulsória, o que acrescenta muito para a baixa alfabetização adulta: $58,6 \%$.

A economia da Eritréia é baseada na agricultura de subsistência. Cerca de $80 \%$ da população se dedica a esta atividade, que corresponde a 12,4\% do PIB (UNOHRLLS 2010b) $)^{38}$. A guerra com a Etiópia entre 1998 e 2000 dizimou a produção econômica, pois impediu acolheita e o plantio de produtos alimentares no oeste do país, região consideravelmente mais fértil e produtiva. A destruição de prédios e bens públicos com a conseqüente dificuldade na prestação de serviços públicos, o deslocamento da população civil e o aumento da crise alimentar aprofundaram a crise econômica. O fim da guerra foi seguido por diversos anos de seca, que aguçaram a crise econômica (WFP 2010) ${ }^{39}$. O governo vem aumentando o seu controle na economia, utilizando-se cada vez mais de empresas estatais e militares para complementar a atividade econômica, havendo poucas empresas privadas no país.

O espalhamento de minas terrestres pelo exército etíope durante a guerra de 1998-2000 prejudica não só o desenvolvimento da agricultura mas também de sua alternativa mais promissora: a mineração. $\mathrm{O}$ fechamento da fronteira econômica com a Etiópia resultou na cessação de atividades comerciais com este país que, anteriormente à guerra, era seu maior parceiro comercial (US DEPARTMENT OF STATE 2010) ${ }^{40}$. A guerra e a seca deixaram dois terços da população dependentes da ajuda humanitária. Metade da população vive abaixo da linha de pobreza, enquanto que os altos setores do governo abarcam grande parte das rendas com seus altos

38 UN-OHRLLS: ERITREIA. 2010b. Disponível em: <http://www.unohrlls.org/en/orphan/83/>. Acesso em 15 de março de 2010.

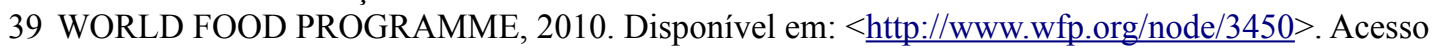
em 15 de março de 2010

40 US DEPARTMENT OF STATE. Background on Eritrea, 2010. Disponível em: $<$ http://www.state.gov/r/pa/ei/bgn/2854.htm $>$. Acesso em 15 de março de 2010 
salários, reservados apenas para aliados. A economia da Eritréia é altamente dependente dos impostos pagos por remessas enviadas por eritreus no exterior às suas famílias. O PIB apresenta baixo crescimento (1,7\% em 2007) e a inflação é alta. O governo tem empregado políticas de nacionalização de empresas e propriedade privada e, associado às confusas leis de investimento, tanto o investimento interno quanto o externo reduziram significativamente (US DEPARTMENT OF STATE 2010). As altas taxas de analfabetismo, de desemprego, de baixa capacitação da população são também empecilhos para o desenvolvimento econômico eritreu.

\section{2 - Eritréia: Quasi-Estado ou Estado Falido?}

Para podermos fazer esta análise, é preciso verificar as condições para a existência do Estado mencionadas anteriormente.

Apesar de possuir as características formais, como o monopólio da força e da lei, uma população, território definido, igualdade no tratamento dos cidadãos, legitimidade perante a população, a representação das vontades, uma constituição cabe olhar estas características mais minuciosamente para ver se são de fato implantadas.

O poder é formalmente divido, porém a concentração dos poderes nas mãos do presidente e seus aliados e a situação de subjugação do judiciário ao executivo já indicam para uma disfunção do Estado: a não-estandardização no tratamento dos cidadãos. Isto implica na idéia de que uns cidadãos (os aliados) são mais cidadãos, possuem mais direitos do que outros (a oposição). Como o Estado deve ser o espaço comum para o exercício da política, a restrição de direitos aos cidadãos torna este espaço restrito. A externação de vontades e desejos dos opositores é encontrada com censura e prisão. A esfera pública fica restrita e a democratização do espaço para a externação dos desejos políticos, que deveria vir com a difusão na sociedade do poder político, não ocorre.

As disputas sobre demarcação de fronteiras tornam incertos os limites territoriais e populacionais. A ausência de controle sobre as fronteiras põe em risco a 
definição jurídica do Estado. O crescente questionamento acerca das ações do governo, sobre suas decisões que incitam mais violência à população abalam a legitimidade do governo perante os olhos da população. A incapacidade de o Estado conseguir prover serviços básicos à população (saneamento, educação, emprego, alimentação), ou até ser motivo da ausência destes serviços (como no caso da segurança) aumentam as desconfianças da população.

Finalmente, a redação e a ratificação da constituição aceita pela população foram passos importantes para reformular e regular as relações sociais e políticas eritréias. Entretanto, a sua não-implantação por tempo indefinido tiram da Eritréia qualquer perspectiva de estabilidade jurídica. A sociedade fica sem o seu pacto e o regramento das atividades políticas, econômicas, sociais, jurídicas fica relegado ao arbítrio do presidente e seu pequeno círculo de aliados próximos. A sociedade permanece desempoderada e sujeita aos desígnios do governo o que fere a característica diferenciadora do Estado dos sistemas políticos anteriores: a criação de um espaço público para ação política dos diversos grupos sociais.

Estes elementos indicam, portanto, a ausência material de elementos definidores do Estado. Não obstante, a recente independência aponta para o início da construção do Estado eritreu, construção esta ainda não encerrada. A ausência de um Estado prévio indica que a Eritréia mais se caracteriza como um quasi-Estado do que como um Estado Falido. As relações de poder na sociedade eritréia se assemelham mais às relações de poder feudais, com o senho feudal e seus servos do que as relações de poder estatais modernas. A sociedade eritréia ainda precisa realizar a distribuição do poder em si, desmanchando as alianças tradicionais e criando um espaço público abrangente com regramento claro para efetivamente tornar-se Estado.

\section{3 - Eritréia e o Estado Falido}

Desde que o FSI começou a ser medido, a Eritréia tem piorado na maioria de seus critérios ${ }^{41}$, o que implica na deterioração da segurança humana neste Estado. No 
que isto diz respeito ao Estado? Ele ainda não consegue lidar com os graves problemas sociais enfrentados causados em boa parte pela guerra e pela crise econômica pela qual passa. A situação indefinida da fronteira com a Etiópia, com a possível volta do conflito interrompe planos de desenvolvimento para a região.

Definir a Eritréia como um Estado falido e menos avançado ajuda sua situação atual? Para os PMAs existe o Programa de Bruxelas que procura desenvolver a economia destes países por meio de parcerias com agências e programas internacionais, em especial as da ONU e das Instituições financeiras internacionais. A proposta é de uma assessoria aos governos locais que contarão com as especificidades de cada Estado, devendo a iniciativa e a continuidade dos projetos caber a estes. Para os Estados falidos, a proposta para a sua recuperação é a de "State Building", acompanhada, para muito autores (o que não é consenso) de "Nation Building", ou seja, a reconstrução do Estado e da nação. Esta solução cabe também aos quasi-Estados. A diferença é que os quasi-Estados já se encontram neste processo, enquanto os Estados falidos precisam recomeça-lo. Todavia, a mesma dificuldade de definição do Estado Falido, a dificuldade em achar o ponto exato que causou o desmoronamento desta instituição, é encontrada na hora de definir onde reconstruir o Estado. A dificuldade de se saber o que construir, o que é o mais adequado para determinado país é enorme. Acrescenta-se a isto que se ignora o fato de que a construção do Estado é um processo longo e que transforma a percepção de política que a população tem. As intervenções internacionais ignoram o fato de que tentativas de se construir um Estado é um processo interno e sua construção de fora para dentro resultarão em mais problemas do que soluções. Para Ghani, Lockhart e Carnahan $(2005)^{42}$, as tentativas de diversas organizações extra-estatais e internacionais ajudarem a população onde o Estado falhou (exemplo: intervenções, ajuda humanitária) apenas prejudicam a criação de um Estado soberano capaz de cumprir com suas funções, o que, posteriormente, prejudica sua legitimidade e seu

Estado, serviços públicos, elites faccionalizadas e intervenção externa. A situação permaneceu a mesma nos indicadores de desenvolvimento desigual e direitos humanos e melhorou nos indicadores de refugiados e aparato de segurança.

42 GHANI, A., LOCKHART, C., CARNAHAN, M. Closing the Sovereignty Gap: An Approach to State-Building. In: Overseas Development Institute, Working Paper 253, Setembro 2005. 20 páginas. 
desenvolvimento.

No final das contas, o FSI é mais uma ferramenta analítica para tornar visível algumas falhas institucionais dos Estados, tornando visível sob a perspectiva da segurança humana os elementos presentes da condição para a existência do Estado. Estes elementos são a base para a construção do Estado e podem apontar para onde os esforço de construção ou fortalecimento do Estado devem ser dirigidos. O como fazer, entretanto, ainda é uma questão complicada, dependente das especificidades de cada país, quasi-Estado ou falido. A necessidade da construção interna, autodeterminada, é sem dúvida condição sine qua non para o sucesso deste processo. 


\section{CONCLUSÃO:}

Este estudo nos permite concluir que a definição corrente de Estado é insuficiente para explicar os diversos fenômenos institucionais e políticos em existência hoje. A dificuldade que encontramos para definir o Estado de maneira a incluir os modelos hoje existentes trespassa para a dificuldade de se achar uma resposta para o porque da falência dos Estados e, mais importante, como estes Estados falidos devem sair desta situação.

Seguindo estritamente a definição atual de Estados, grande parte dos Estados hoje considerados falidos não podem ser considerados materialmente como Estados. O processo da construção do Estado nestes casos foi iniciado porém nunca se completou ou chegou num patamar de estabilidade. Não houve uma reorganização social interna que tornasse a construção do Estado uma necessidade. Enfim, as condições para a existência do Estado não são encontradas nestes casos. A definição de Estado falido, portanto, é completamente inadequada em muitos casos dos novos Estados resultantes das descolonizações da década de 1950 e 1960, visto que ela pressupõem que houve um Estado e que ele deu errado. A definição de quasi-Estado é mais adequada para estes casos, e, mais importantemente, leva à uma diferente percepção acerca do fenômeno. A construção do Estado é um processo complexo, bastante demorado e que leva à reorganização da sociedade como um todo, batalhando com as formas tradicionais do poder, criando e reformulando identidades. É um processo doloroso, mas sobretudo um processo interno. As constantes intervenções em nome da humanidade, as ajudas externas, apesar de necessárias em muitos casos, solapa a base da pouca legitimidade destes quasi-Estados dificultando mais ainda o processo de construção do Estado. A questão acerca de como promover a estabilidade e o desenvolvimento deles ainda é tema bastante complicado e controverso.

Os critérios de classificação do Failed State Index e dos PMA nos levam a fazer outras considerações acerca do Estado. Isto porque, em última instância, o que estes índices procuram identificar é a qualidade de vida dos cidadãos do Estado: a 
estabilidade política que proporciona a paz, a segurança, a existência de uma espécie de ágora, para a externação de desejos individuais e coletivos. A evolução dos direitos humanos durante o século XX, acompanhada de uma evolução do conceito de ser humano como ser-cidadão traz implicações políticas extremamente complicadas. A função do Estado é incrementada como bastião dos direitos humanos (não só os da primeira geração, mas também os de segunda e terceira), e a incapacidade de o Estado de garantir estes direitos é hoje suficiente para considerar o Estado como falido.

A estigmatização de um Estado como falido leva à diversos problemas. $\mathrm{O}$ primeiro, é que a soberania destes Estados é considerada relativa. Apesar do direito à autodeterminação, intervenções, sanções, ocupações são conseqüências bastante recorrentes às notícias e denúncias de caos interno e desrespeito aos direitos humanos. O fato de muitos dos Estados falidos serem bastante ricos em recursos naturais inexplorados tornam estas interferências bastante prolongadas e nada apaziguadoras, como no caso do Iraque, rico em petróleo. A denominação de um Estado como falido portanto, interrompe o próprio processo de reabilitação pelo fato de muitas das características próprias do Estado estarem sujeitas ao crivo internacional. A soberania, a autodeterminação e a redistribuição de poder na sociedade são limitadas por fora, o que torna um processo interno quase impossível. 


\section{REFERÊNCIAS BIBLIOGRÁFICAS}

AKPAN, Felix. Road Map to Failed State: The Nexus Between Bad Governance and Failed State. Pakistan Journal of Social Sciences, vol. 5. nº 9, 2008. Páginas 945952

BADIE, Bertrand et BIRNBAUM, Pierre. Sociologie de l'État. Paris, Grasset, 1982. 238 páginas

BAS ART. Non-State Actors in Global Governance: Three Faces of Power. 2004. 54 páginas. Tese de Doutorado - University of Nijmegen. Bonn, abril de 2003. Tese digital pág. 27 Disponível em:

http://www.essex.ac.uk/ecpr/events/jointsessions/paperarchive/edinburgh/ws11/arts.p df. Acesso em: 19/03/2010.

BILGIN, P \& MORTON, A.D. (2002). Historicizing Representations of 'Failed States': Beyond the Cold-War Annexation of the Social Sciences? Third World Quarterly, Vol. 23, $\mathrm{n}^{\circ} 1$ (fevereiro). Páginas 55-80

BROOKS, R. E. (2005). Failed State or the State as Failure? The Chicago Law Review, Vol. 72, No 4 (fall). Páginas 1159-1196.

DI JOHN, Jonathan. Conceptualizing the Causes and Consequences of Failed States: A Critical Review of the Literature. In: Crisis States Working Paper $\mathbf{n}^{\mathbf{0}} 25$ Series $\mathbf{n}^{0}$ 2, London, LSE Development Studies Institute: 2008. 51 páginas.

DORFF, Robert H. Dorff. (2005) "Failed States after 9/11: What Did We Know and What Have We Learned?”. International Studies Perspectives. Vol 6. Páginas 2034

DORMAN, Sarah Rich. Eritrea's Nation and State-building: Re-assessing the impact of the struggle. In: Conference on Globalisation and Self-Determination. Working Paper Number 105 London, 4 de abril de 2003. 19 páginas.

ESTADOS UNIDOS_ Executive Office of the President. National Strategy for Combating Terrorism. Fevereiro 2003. 30 páginas.

FUND FOR PEACE. Failed State Index. 2009a. Disponínvel em:

$<\underline{\text { http://www.fundforpeace.org/cast/index.php? }}$ option $=$ com content\&task $=$ view\&id=14\&Itemid $=30>$. Acessado em 13 de março de 2010 .

FUND FOR PEACE. Eritrea counry Profile. 2009b Dispoível em:

$<$ http://www.fundforpeace.org/web/index.php? option $=$ com_content\&task $=$ view\&id $=396 \&$ Itemid $=555>$ Acessado em 15 de março 
de 2010.

GHANI, A, LOCKHART, C. \& CANAHAN, M. An Agenda for State-Building in the Twenty-First Century. The Fletcher Forum of World Affairs, Vol 30: 1 (winter), 2006. Páginas 101-126.

GHANI, A.,LOCKHART, C., CARNAHAN, M. Closing the Sovereignty Gap: An Approach to State-Building. In: Overseas Development Institute, Working Paper 253, Setembro 2005. 20 páginas.

GÓIS A. C. L. E BARROS-PLATIAU, A. F. Direito Internacional e Globalização Face às Questões de Direitos Humanos. In: RIBEIRO, M. de F. e Valério de Oliveira Mazzuoli (coords) Direito Internacional dos Direitos Humanos: estudos em homenagem à professora Flávia Piovesan. Curitiba: Juruá, 2004. 432 páginas.

GROS, Jean-Germain (1996). Towards a Taxonomy of Failed States in the New World Order: Decaying Somalia, Liberia, Rwanda and Hainti. Third World Quarterly, Vol 17, nº 3. Páginas 455 a 471

HEHIR, Aidan (2007). The Myth of the Failed State and the War on Terror: A Challenge to the Conventional Wisdom. Journal of Intervention and Statebuilding. Vol. 1 n 3 . Páginas. 307-332.

HELMAN, G.B. \& RATNER, S.R. Saving Failed States. Foreign Policy, No. 89 (winter), 1993. Páginas 3-20.

HERZ, Mônica. Teoria das Relações Internacionais no Pós-Guerra Fria. Dados, Rio de Janeiro, v. 40, n. 2, 1997. Disponítvel em: http://www.scielo.br/scielo.php? $\underline{\text { script }=\text { sci arttext\&pid }=\text { S0011-52581997000200006\&lng=en\&nrm=iso }}$. Acesso em: 12 Fev. 2010. doi: 10.1590/S0011-52581997000200006.

HOBSBAWM, Eric. 1996a. Age of Revolutions: 1789-1848. Nova Iorque, Vintage Books. 368 páginas

HOBSBAWM, Eric. 1996b. The Future of the State. Developmente and Change, vol. 27, n. 2. Páginas 267-278.

HOBSBAWM, Eric. A Era dos Extremos: O Breve Século XX: 1914-1991. Tradução de Marcos Santarrita; Revisão Técnica de Maria Célia Paoli. São Paulo, Companhia das Letras, 1995. 632 páginas.

HOBSBAWM, Eric. Age of Empires: 1875-1914. Nova Iorque, Vintage Books: 1989. 404 páginas.

JACKSON, Robert. Quasi-states: Soverignty, International Relations and the Third World. Cambridge: Cambridge Studies in International Relations, 1990. 255 
páginas.

JACKSON, R \& ROSBERG, C. Why Africa's Weak States Persist: The Empirical and the Juridical in Statehood. World Politics, Vol. 35, n 1, outubro 1982. Páginas $1-24$.

LIBRARY OF CONGRESS COUNTRY PROFILE, Washington D.C. Disponível em: $<$ http://lcweb2.loc.gov/frd/cs/profiles/Eritrea.pdf $>$. Acessado em 15 de março de 2010 .

LITWAK, Robert S. Rogue States and US Foreign Policy: Containment After the Cold War. Washington DC, Woodrow Wilson Center Press, 2000. 290 páginas.

MÉNY, Yves. Les Politiques du Mimétisme Institutionnel: La greffe et le rejet. Paris, Harmattan: 1993. 285 páginas.

MILLIKEN, J \& KRAUSE, K. State Failure, State Collapse and State Reconstructuion: Concepts, Lessons and Strategies. In: MILLIKEN, Jennifer (ed.) State Failure, State Collapse and Reconstruction. Cornwall, Blackwell Publishing, 2003. 325 páginas.

MONTEIRO, Leandro N. O Conceito de Estados Fracassados nas Relações Internacionais: Origens, Definições e Implicações Teóricas. Dissertação de mestrado (134p.) Programa de Pós-Graduação em Relações Internacionais, Universidade Paulista "Júlio de Mesquita Filho", Universidade de Campinas e Pontifícia Universidade Católica de São Paulo. São Paulo, 2006.

NETTELS, Curtis. British Mercantilism and the Economic Development of the Thirteen Colonies. Journal of Economic History. Vol. 12, Spring n², 1992. Páginas 105-114.

ORGANIZAÇÃO DAS NAÇÕES UNIDAS. A More Secure World. relatório apresentado na 59a Assembléia Geral das Nações Unidas em 2 de dezembro de 2004. 99 páginas.

REUTER, Paul. Instituições Internacionais. Prefácio de Antônio da Costa Lôbo. Lisboa, Edições Rolim: 1980. 373 páginas.

REUTER, Paul. Introducción al Derecho de Los Tratados. Traducción de Eduardo L. Suárez. México, Universidad Nacional Aunónoma de México: 1999. 340 páginas.

RODRIGUES, Simone M. Inserção Internacioal de Quasi-Estados no Século XX: A Política das Nações Unidas. Revista Cena Internacional 3 (1), 2001. Páginas 133152.

SARAIVA, JFS (org). História das Relações Internacionais Contemporâneas: da 
Sociedade Internacional do Século XIX à era da Globalização. São Paulo: Ed. Saraiva, 2007. 247 páginas.

SMOUTS, Marie-Claude. As Novas Relações Internacionais: Práticas e Teorias. Brasília, Editora Universidade de Brasília: 2004. 408 páginas.

UN-OHRLLS (United Nations Office of the High Representative for the Least Developed Countries, Landlocked Developing Countries and the Small Island Developing States). 2010a. Disponível em: $<\underline{\text { http://www.unohrlls.org/en/ldc/25/> }}$. Acesso em 13 d março de 2010 UN-OHRLLS: ERITREIA. 2010b. Disponível em:

$<$ http://www.unohrlls.org/en/orphan/83/>. Acessado em 15 de março de 2010.

UN \& WORLD BANK. Measuring Progress in Least Developed Countries. Documento apresentado na $61^{\mathrm{a}}$ Assembléia Geral das Nações Unidas em Setembro de 2006. Disponível em:

$<$ http://www.unohrlls.org/UserFiles/File/Publications/progress $\% 20 \mathrm{in}$ \%20LDCs.pdf $>$. Acessado em 13 de março de 2010.

US DEPARTMENT OF STATE. Background on Eritrea, 2010. Disponível em: $<$ http://www.state.gov/r/pa/ei/bgn/2854.htm $>$. Acesso em 15 de março de 2010 